A Disseminated Silver-LeadZinc Sulfide Occurrence at Hahns Peak, Routt County, Colorado GEOLOGICAL SURVEY BULLETIN 1367

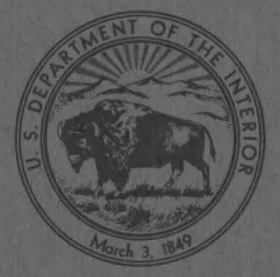




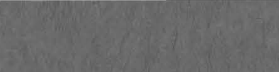




\section{A Disseminated Silver-Lead-}

\section{Zinc Sulfide Occurrence at}

\section{Hahns Peak, Routt County,}

\section{Colorado}

By E. J. YOUNG and KENNETH SEGERSTROM

GE OL O I C A L S U R VEY B U L L E T I N 1367

Investigation of an upper Tertiary

hydrothermally altered and

mineralized stock in the

Elkhead Mountains,

northwest Colorado

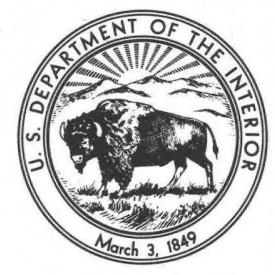




\section{UNITED STATES DEPARTMENT OF THE INTERIOR}

ROGERS C. B. MORTON, Secretary

\section{GEOLOGICAL SURVEY}

V. E. McKelvey, Director

Library of Congress catalog-card No. 72-600326

For sale by the Superintendent of Documents, U.S. Government Printing Office, Washington, D.G. 20402 - Price: Paper Cover $-\$ 1.50$ domestic postpaid, or $\$ 1.25$ GPO Bookstore Stock Number 2401-00276 


\section{CONTENTS}

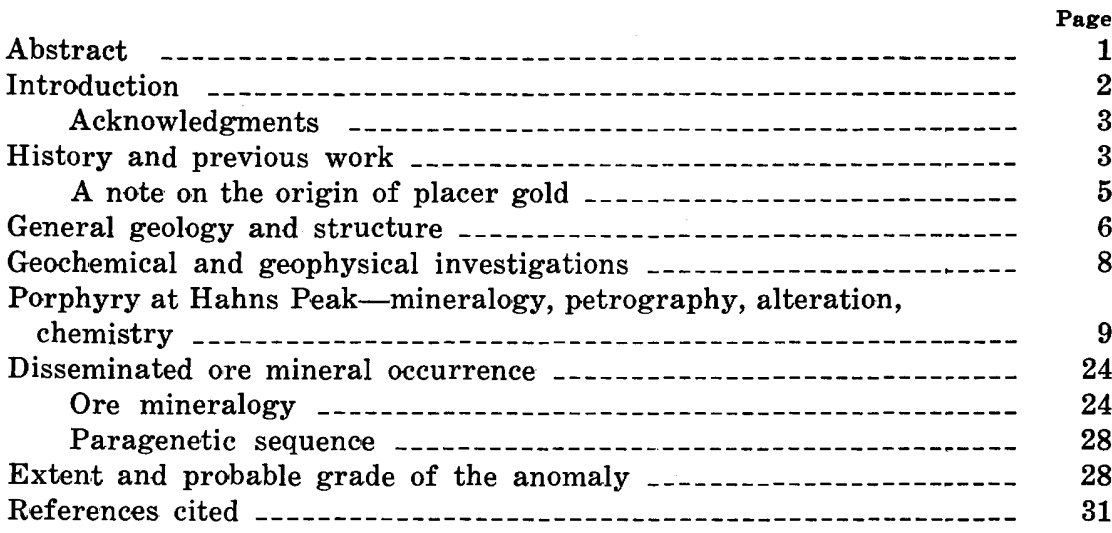

\section{ILLUSTRATIONS}

[Plates are in pocket]

Plate 1. Geologic map and section of Hahns Peak area, Routt County, Colorado.

2. Diagrammatic representation of core $7 \mathrm{~A}$ showing modal mineralogy of porphyry at Hahns Peak, Routt County, Colorado.

3. Sections showing silver, lead, and zinc values in adit $7 \mathrm{D}$ and in drill holes 3, 7A, D2, D4, and 37, Hahns Peak, Routt County, Colorado.

Figure 1. Index map of Hahns Peak and Farwell Mountain quadrangles

2. Maps showing surface geochemical anomalies for silver, copper, lead, and zinc in the Hahns Peak area -....-

3. Map showing induced polarization survey on Hahns Peak

Page 1 2 3 3 5 6 8 
Figures 7-12. Photomicrographs-Continued

10. Proustite prisms -

11. Crusts of variscite lining a cavity --_----- 27

12. Botryoids of wavellite in a cavity -...-.- 28

\section{TABLES}

TABLE 1. Chemical, spectrographic, and modal analyses of porphyry at Hahns Peak

Page

2. Modal analyses of porphyry at Hahns Peak in core 7A_-

3. Spectrographic analysis of porphyry at Hahns Peak in core $7 \mathrm{~A}$

4. Spectrographic analyses of pyrite concentrates from porphyry at Hahns Peak

5. Average values for $\mathrm{Ag}, \mathrm{Pb}, \mathrm{Zn}, \mathrm{Cu}$, and $\mathrm{Mo}$ in Hahns Peak drill holes and adits, and comparison with crustal abundances 


\title{
A DISSEMINATED SILVER-LEAD-ZINC SULFIDE OCCURRENCE AT HAHNS PEAK, ROUTT COUNTY, COLORADO
}

\author{
By E. J. Young and Kenneth Segerstrom
}

\begin{abstract}
Geophysical and geochemical surveys have revealed silver, lead, and zinc anomalies on Hahns Peak. These anomalies are interpreted on the basis of information from core drilling, aggregating more than 22,000 feet of core, exploratory tunneling, geologic mapping, and chemical and mineralogic work. Placer gold on and surrounding Hahns Peak is generally thought to have been derived from the porphyry, but the paucity of gold in the porphyry makes this source unlikely.

The porphyry at Hahns Peak, which consists of a central stock, associated dikes, and many irregular branching sills, has domed and intruded rocks that range in age from Precambrian to Miocene. The time of intrusion is about 11 million years ago, and at least some extrusive activity is indicated by the presence of tuff breccia on the peak 1 mile west-northwest of Hahns Peak. Mineralizing hydrothermal solutions invaded the Hahns Peak breccia pipe during or after its formation. Originally quartz latitic or dacitic in composition, the porphyry at Hahns Peak is now rhyolitic, and it contains sanidine, albite, and quartz as major minerals. The main hydrothermal alterations or additions are the result of silicification, sericitization, kaolinization, and pyritization. Minor alterations or additions are the formation of jarosite, limonite, montmorillonite, sanidine, anatase, and manganosiderite.

Pyrite, usually as pyritohedrons less than 1 millimeter in size, occurs disseminated throughout the breccia pipe in amounts averaging about 2 percent. Ore minerals, also as disseminations, occur sporadically in certain zones in the breccia pipe. Galena and sphalerite are the two most abundant ore minerals, a silver-bearing tetrahedrite and chalcopyrite are less abundant, and proustite and covellite are sparse. Variscite commonly accompanies the ore minerals, wavellite less commonly. These hydrous aluminum phosphates resulted from the liberation of phosphate ions during breakdown of primary fluorapatite and consequent combination with alumina from breakdown of albite.
\end{abstract}

In 1,306 samples of drill core, silver content averages 9.7 ppm (parts per million) (140 times crustal abundance), lead $1,100 \mathrm{ppm}$ (55 times crustal abundance), molybdenum $10.4 \mathrm{ppm}$ (10 times crustal abundance), zinc $600 \mathrm{ppm}$ (7.5 times crustal abundance), and copper $100 \mathrm{ppm}$ (two times 
crustal abundance). Gold content of these samples was generally below detection limits. The most promising mineralized zone contains $16 \times 10^{8}$ cubic feet of rock, estimated to contain 26 tons of silver at a grade of 0.58 ounce per short ton, 6,500 tons of lead at a grade of 0.5 percent, and 2,600 tons of zinc at a grade of 0.2 percent. On a larger scale, in terms of a lower grade resource, a volume of $8.7 \times 10^{9}$ cubic feet is estimated to contain 7,100 tons of silver at a grade of 0.29 ounce per short ton, 710,000 tons of lead at a grade of 0.1 percent, and 430,000 tons of zinc at a grade of 0.06 percent.

\section{INTRODUCTION}

This report presents the results of geologic and related studies conducted on Hahns Peak, Routt County, Colo., as part of a general investigation by the U.S. Geological Survey to determine the economic mineral potential of the region. The Hahns Peak area is near the north boundary of Colorado, about 20 miles north of Steamboat Springs and 8-10 miles west of the Continental Divide which is at the crest of the northern Park Range. The area is at the extreme east end of the Elkhead Mountains. These geographic relations are shown in figure 1.

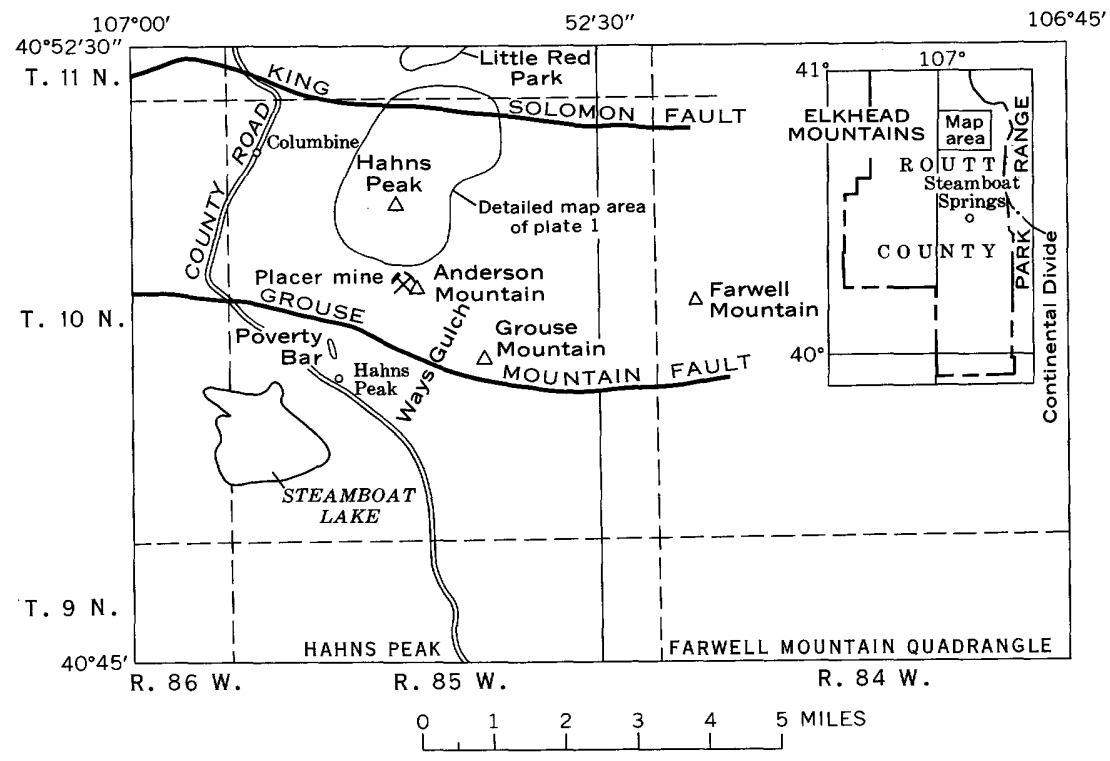

Figure 1.-Hahns Peak and Farwell Mountain quadrangles.

The geology of Hahns Peak and vicinity (fig. 1) was mapped in the summers of 1966-67 by Segerstrom, assisted by Stephen H. Kirby. The Precambrian part of the Hahns Peak quadrangle 
was mapped in the summer of 1967 by Young, assisted at times by Kirby; the Farwell Mountain quadrangle was mapped during the summer of 1968 and during 2 weeks in 1969 by Segerstrom and Young. The general geology of the two quadrangles was described by Segerstrom and Young (1972).

Geochemical and geophysical data obtained from William A. Bowes and Associates indicated a silver-lead-zinc anomaly in the area. The geochemical survey was based on samples of soil or, where no soil existed, on surficial rock chips taken on north-south lines spaced 1,500 or 750 feet apart over an area of about 12 square miles. Typically, spacing between samples on a travense was 400 feet. The geophysical data were obtained by a directcurrent pulse-transient I.P. (induced polarization) survey, using a three-array electrode spacing. Largely on the basis of geochemical and geophysical surveys, Bowes and Associates conducted a core drilling program, which involved 38 drill holes aggregating more than 22,000 feet. Most holes were drilled $50^{\circ}$ from the horizontal, several were vertical, and one was horizontal. The longest and deepest drill hole (IS-7A) was 3,173 feet. Most of the mineralogic work of this report is based on detailed studies of this core by Young.

Under Bowes' direction, an exploratory horizontal adit (7D) was driven 1,742 feet, and from its terminus a 1,377-foot horizontal hole (7D2) was drilled. An old adit, the Southern Cross, which penetrated 973 feet, was reopened by the U.S. Geological Survey in 1967. Drill holes and adits are shown on plate 1 .

\section{ACKNOWLEDGMENTS}

We thank Stephen H. Kirby, Larry Segerstrom, and William Bush, Jr., for conscientious field assistance. Paul K. Theobald provided geochemical data. We are especially grateful to William A. Bowes and his coworkers for warm unstinting cooperation, for permitting access to drill core collections and exploration records, and for permission to publish data.

\section{HISTORY AND PREVIOUS WORK}

Probably the best account of the discovery and history of the gold placers on Hahns Peak was written by Parker (1961), who stated that,

According to Hall (1895, p. 300-302) the Hahns Peak placers were discovered by a Captain Way in 1864. He returned to Empire [Colo.] and there told John Hahn of his discovery. The following year Hahn, with W. A. Doyle, went to the area and prospected it. They returned in 1866 with a party of 40 men who built cabins near the site of the village of Hahns Peak and placered through the summer. These men established a mining district, nam- 
ing it and the peak in honor of Hahn. Faced by an early winter that year the men returned, leaving Hahn and Doyle. During the spring of 1867 these two men were forced to return to Empire for supplies and were caught in a severe snowstorm on the Gore Range, where Hahn died.

After Way's discovery, the placers were worked sporadically until about 1910, and they were worked for a short time in the 1930's. Fred Ward operated the gold placer mine about 1 mile south of the summit of Hahns Peak during the 10 years previous to 1969 .

Hahns Peak was first mentioned in geologic literature by Emmons (1877), who made a field trip in the area in 1872 . King (1878) gave a general discussion of the Elkhead Mountains.

In 1906 Gale discussed the character and genesis of the Hahns Peak gold deposits. At that time placers were worked in two areas. The smaller area consisted of the bar immediately west of Ways Gulch and the stream-level gravel of Ways Gulch at the western foot of Grouse Mountain, reputedly the richest of the workings. The larger and more extensively worked area, Poverty Bar near the village of Hahns Peak, reportedly yielded $\$ 84,000$ worth of gold in one summer. Gale (1906) stated that the Hahns Peak placer gold is in large part moderately coarse flake gold, and that it is alloyed with considerable silver. Many very small nuggets were found enclosed in vein quartz. According to del Rio (1960) the value of precious and base metals mined from Routt County from 1873 to 1960 did not exceed $\$ 500,000$.

George and Crawford (1909) discussed the Hahns Peak placers and searched-for lodes and concluded that the source of the gold was still in doubt. The three possible sources they considered were (1) the porphyries at Hahns Peak, (2) the basal conglomerate of the Dakota Sandstone, and (3) the metamorphic rocks of the Precambrian area. Christensen (1942) described the igneous geology of the Elkhead Mountains. The geology in and around the Hahns Peak area was described by Barnwell (1955), Hunter (1955), Murphy (1958), and McConnell (1960). Buffler (1967) studied the Browns Park Formation and its relation to the late Tertiary geologic history of the Elkhead Mountains region.

Recent U.S. Geological Survey investigations, other than our own, began in 1966. At that time Paul K. Theobald made geochemical surveys on and around Hahns Peak which involved sampling soil and stream sediments and collecting surficial rock chips.

Several people with the U.S. Geological Survey contributed to the analytical work in the present study. Spectrographic analyses 
for 30 elements in more than 1,300 rock samples from underground workings and drill core were made by J. M. Motooka. Splits of 98 of these samples were reanalyzed by the atomic absorption method for $\mathrm{Cu}, \mathrm{Pb}$, and $\mathrm{Zn}$ by $\mathrm{J}$. R. Hassemer and for $\mathrm{Au}$ by J. G. Frisken and R. N. Babcock. Fire assays for Ag of these 98 samples were made by R. R. Carlson and Z. C. Stephenson.

Gosling, Jenne, and Chao (1971), who studied gold in natural waters at Hahns Peak and other places, reported that in natural waters gold values, "solute" plus particulate, ranged from 0 to 150 nanograms per liter (parts per trillion) and were unrelated to rock or water types. "Solute" gold concentrations were generally higher than particulate gold concentrations. "Solute" gold represented the gold passing $0.1 \mu$ membrane filter, whether in true solution, as an organic or inorganic complex, or as a colloid. Their data suggest the occurrence of a spring flushout of "solute" gold in ground-water discharge during the snowmelt recharge period, but indicate that direct hydrogeochemical prospecting for gold is not promising. G. A. Desborough (unpub. data, 1969) made microprobe studies on gold inclusions found in pyrite from the Royal Flush mine on Hahns Peak and on placer gold from Little Red Park. He found that the silver content of the centers of 14 gold grains from Little Red Park averaged 36.8 weight percent and ranged from 26.0 to $\mathbf{5 7 . 5}$ weight percent. Similar data from six gold inclusions in pyrite from the Royal Flush mine yielded a silver content range of 29.0 to 41.0 percent and an average of 36.3 percent. Thus the silver content of gold from the rocks of Hahns Peak is virtually identical to the silver content of the placer gold from Little Red Park.

Antweiler and Sutton (1970) made a spectrographic study of 174 samples of native gold (mostly placer) from the Rocky Mountain States; five of these samples came from the Hahns Peak area.

Antweiler, Doe, and Delevaux (1972) concluded from lead isotope data that placer gold found on and around Hahns Peak originated in the porphyry at Hahns Peak.

\section{A NOTE ON THE ORIGIN OF PLACER GOLD}

The origin of the placer gold surrounding Hahns Peak is still uncertain despite several investigations. One of the occurrences of gold that we studied bears on the origin of some of the placer gold. At the head of Ways Gulch, in the saddle between Anderson and Grouse Mountains, a gold-bearing blue-gray clay just below the soil level contained the following constituents in order of decreasing abundance: angular fragments of porphyry, 
colorless to pale-pink well-rounded (some almost spherical) zircons as much as $3 \mathrm{~mm}$ in diameter, magnetite and hematite grains as much as $5 \mathrm{~mm}$ in diameter, pink euhedral to rounded garnets as much as $3 \mathrm{~mm}$ in diameter, euhedral colorless apatite grains less than $1 \mathrm{~mm}$ long, reddish-orange euhedral zircon grains less than $1 \mathrm{~mm}$ long, and traces of epidote and gold. The porphyry fragments, apatite, and smaller reddish-orange zircons are identical with those from the porphyry at Hahns Peak. A possible source for the other constituents is either the basal conglomerate of the Browns Park Formation or the conglomerate at the base of the Dakota Sandstone. The Precambrian rocks are not a likely source for the coarse-grained rounded zircons as they are not known to occur in the Precambrian rocks of the region. The coarse-grained rounded zircons are also foreign to the porphyry at Hahns Peak. Thus, because some components associated with gold in the blue-gray clay were derived from sources other than the porphyry, other sources for the gold cannot be ruled out.

\section{GENERAL GEOLOGY AND STRUCTURE}

The geology of the Hahns Peak area is only briefly discussed here inasmuch as it has already been described in detail (Segerstrom and Young, 1972). The Hahns Peak quadrangle is located at the intersection of the west-trending volcanic Elkhead Mountains of Tertiary age with the north-trending Park Range which is of Precambrian age.

A Precambrian basement complex of gneiss, schist, and minor quartzite lies about 2 miles east of Hahns Peak and is in thrust contact with rocks of Mesozoic age. The rocks of Mesozoic age, which are widely distributed in the central and western parts of the Hahns Peak quadrangle, consist of the Permian and Triassic Goose Egg and Red Peak Formations, the Triassic Jelm and Popo Agie Formations, the Triassic (?) Bell Springs Member of the Nugget Sandstone, the Jurassic Sundance and Morrison Formations, and the Cretaceous Dakota Sandstone and Mancos Shale. The Triassic and Jurassic units, composed largely of weakly cemented sedimentary clastic rocks, are poorly exposed and deeply weathered in most outcrops. The Dakota Sandstone is about 100 feet thick and consists of well-lithified sandstone and conglomerate which form a protective capping over the Jurassic rocks. Only the lower 900 feet of the Mancos Shale is exposed. The Mancos Shale locally forms hummocky landslide topography.

The Cenozoic Era is represented in the Hahns Peak quadrangle by the Browns Park Formation, by porphyry which intrudes the 
Browns Park and older formations, by an erosional remnant of tuff breccia, and by unconsolidated colluvial and alluvial deposits. The Browns Park Formation, of late Miocene and Pliocene(?) age, unconformably overlies the Mancos Shale and older rocks with a basal conglomerate consisting of Precambrian cobbles and pebbles. According to Barnwell (1955) the formation attains a regional thickness of about 1,200 feet. The maximum thickness in the northern part of the Hahns Peak quadrangle, as determined by drilling, is a little more than 600 feet.

Porphyries are generally of the intermediate type (dacite and quartz latite), but the porphyry at Hahns Peak has been hydrothermally altered to the composition of rhyolite. Detailed petrography is given in the chapter of this report on the porphyry. Particulars on age determination of the porphyry at Hahns Peak are given by Segerstrom and Young (1972). Time of intrusion is about $11 \pm 1$ million years ago.

The Precambrian rocks are tightly folded along axes whose dominant trend is east-northeast. These rocks are thrust westward over gently folded Mancos Shale and older Mesozoic strata, and the thrusting locally produces steep dips and overturning of the sedimentary beds. Time of thrusting was probably early Tertiary.

High-angle faults have displaced the folded and overthrust rocks and form an east-striking horst about 15 miles long and 4 miles wide which occupies more than half the Hahns Peak quadrangle and extends east and west beyond the quadrangle limits. The horst is bounded on the north by the King Solomon fault, where a 600-foot vertical displacement of the Browns Park Formation was measured by core drilling directly north of Hahns Peak. The Grouse Mountain fault at the south edge of the horst is poorly exposed or is concealed by alluvium, but displacement is estimated at probably not more than 500 feet.

The Browns Park and older formations are domed by the intrusion at Hahns Peak about 2 miles west of the thrust contact with the Precambrian rocks. The flanking sedimentary beds generally dip moderately away from the peak but locally are steeply tilted or overturned. Similar intrusions elsewhere in the quadrangle seem to have had lesser doming effects on the intruded rock. The intrusion is composed of a central stock, associated dikes, and many irregular branching sills that dip away from the center of the stock as shown on the section of plate 1 .

The doming of Hahns Peak probably began during active stages of volcanism in the Elkhead Mountains. The erosion of 
the tuff breccia that once covered Hahns Peak seems to have been almost completed, as only one remnant of extrusive rock related to the porphyry at Hahns Peak has been found (Segerstrom and Kirby, 1969). Intrusive pressures that probably were released locally by eruption of tuff breccia and regionally by extrusion in the Elkhead Mountains farther west caused withdrawal of the magma column and collapse of the dome, which then led to the formation of a breccia pipe at Hahns Peak.

The intensity of dislocation and brecciation at the margins of the breccia pipe is evidenced by fallen blocks of altered Morrison sandstone encountered in drill hole 7A, 2,500 feet below the upturned edges of the formation. Soft black shales of the Mancos Shale, which have been plastically deformed at the edges of the pipe, constitute much of the matrix of the marginal porphyry breccia which lies in a zone as much as 300 feet wide.

Section $A-A^{\prime \prime}$ on plate 1 illustrates our interpretation, diagrammatic in part, of the configuration of the Hahns Peak breccia pipe. The section is based on drill-hole data obtained from William A. Bowes and from our surface mapping.

\section{GEOCHEMICAL AND GEOPHYSICAL INVESTIGATIONS}

Areas of anomalously high values for silver, lead, zinc, and copper are shown in figure 2 , which was prepared from compilation of geochemical data. Silver and lead show pronounced anomalies around Hahns Peak, and in outlying areas they show smaller anomalies associated with porphyry exposures or with proximity to the overthrust contact. Copper anomalies are best developed over Precambrian terrane, especially in the vicinity of the Farwell mine shafts. Zinc anomalies are smaller and weaker than those of lead because: (1) zinc is not as abundant as lead in the porphyry; and (2) although both galena and sphalerite oxidize readily to the sulfate, lead sulfate is relatively insoluble, whereas zinc sulfate is very soluble. The difference in solubility of lead sulfate and zinc sulfate would also explain the lack of spatial correlation in the anomalies of these two metals.

Most of the core drilling was located on anomalies indicated by a direct-current pulse-transient I.P. survey contracted for by W. A. Bowes. High resistivity anomalies were found over Hahns Peak and immediately to the southeast as shown in figure 3 . The 8-millisecond chargeability contour, shown in the figure, represents relatively longer retention of electric charge by disseminated pyrite. 


\section{PORPHYRY AT HAHNS PEAK-MINERALOGY, PETROGRAPHY, ALTERATION, CHEMISTRY}

The entire core of drill hole 7A, 3,173 feet, has been inspected visually, much of it under the binocular microscope. About 150 $\mathrm{X}$-ray analyses were made of material obtained throughout its length to help identify mineral phases or to verify preliminary determinations. In addition, chemical and spectrographic analyses and study of thin and polished sections have aided understanding of petrography and ore-mineral relations. These data are summarized diagrammatically on plate 2 , which shows the distribution of rock minerals, alteration minerals, ore minerals, and accessory minerals, and which gives textural information for the whole core.

The most significant characteristic of the porphyry is its alteration. This alteration varied with depth and structure and, in general, resulted in a bleached, almost white rock which commonly contains small cavities. The least altered rock, generally found at depth, is grayish white with a pale tint of blue; the plagioclase phenocrysts are albite. By contrast, the most altered rock contains pseudomorphs of sericite after plagioclase.

Phenocrysts in the least altered porphyry generally constitute 20-50 percent of the rock. Most of the phenocrysts are 1-5 $\mathrm{mm}$ in maximum dimension, but some are as large as $5 \mathrm{~cm}$. The groundmass is holocrystalline but very fine grained; the grains are $<0.004$ to about $0.020 \mathrm{~mm}$ in diameter. Most large phenocrysts tend to be euhedral or subhedral, whereas many small ones seem to be brecciated. Quartz phenocrysts are generally rounded and embayed. Potash-rich sanidine and albite are present as phenocrysts. Some sanidine phenocrysts are mantled by secondary albite (fig. 4) ; others exhibit skeletal forms, indicating solution effects, but no sericitization. Original biotite phenocrysts are bleached and altered to sericite. Secondary phenocrysts of fuchsite, which contain as much as 1 percent chromium, are sparse. Disseminated pyrite, usually as pyritohedrons less than $1 \mathrm{~mm}$ in size, makes up 1-2 percent of the porphyry. Colorless apatite and, more rarely, pink zircon (fig. 5) occur as secondary minerals. The apatite has an omega refractive index of $1.635 \pm 0.001$, which classifies it as fluorapatite. The zircon occurs as euhedral crystals, some of which are zoned.

Inasmuch as other porphyries surrounding Hahns Peak contain oligoclase rather than albite and are quartz latitic or dacitic in composition, the porphyry at Hahns Peak was probably of similar composition before albitization. The porphyry at Hahns Peak is now rhyolitic in composition. 


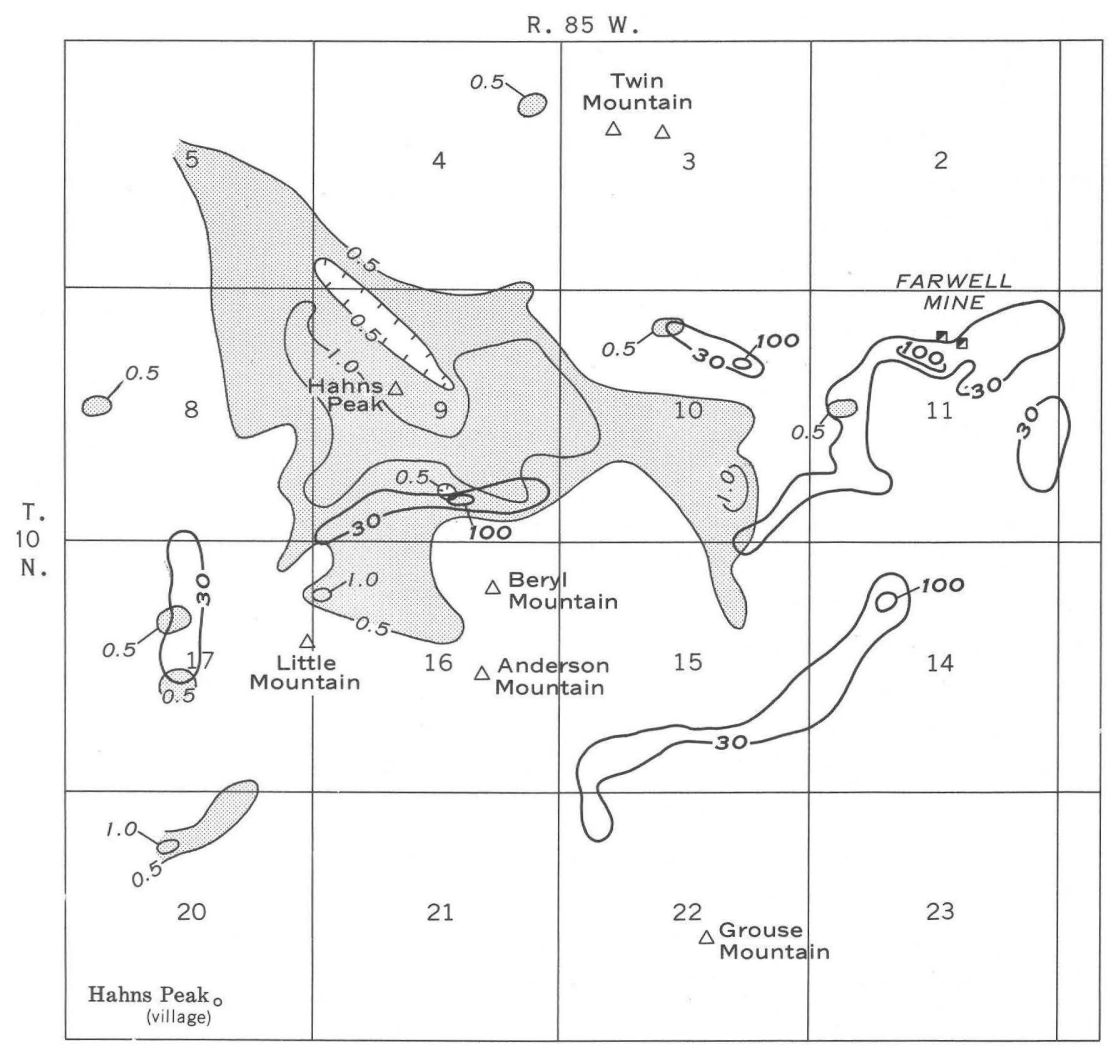

$A$

Figure 2.-Surface geochemical anomalies for silver, copper, lead, and zinc soil samples taken on north-south lines 750-1,500 feet apart; spacing toured on 0.5 and $1.0 \mathrm{ppm} ; \mathrm{Cu}$, on 30 and $100 \mathrm{ppm} . B, \mathrm{~Pb}$, on 50,100 ,

Two varieties of porphyry are exposed at the surface, a mauvecolored rock and a strongly bleached cream-colored rock (samples $1 \mathrm{~S}$ and $2 \mathrm{~S}$, table 1 ). The sample of mauve-colored rock contains about 15 percent phenocrysts of sanidine, albite, and a little biotite. The groundmass is very fine grained $(<0.02 \mathrm{~mm})$ and must contain considerable quartz in addition to feldspar, as $\mathrm{X}$-ray analysis shows the major constituents to be quartz, plagioclase, and potassium feldspar. Sericite, biotite, and kaolinite are minor constituents.

The sample of cream-colored rock contains about 30 percent phenocrysts of sanidine, albite, quartz, and sericite. The groundmass is also very fine grained, and the texture appears more 
R. $85 \mathrm{~W}$.

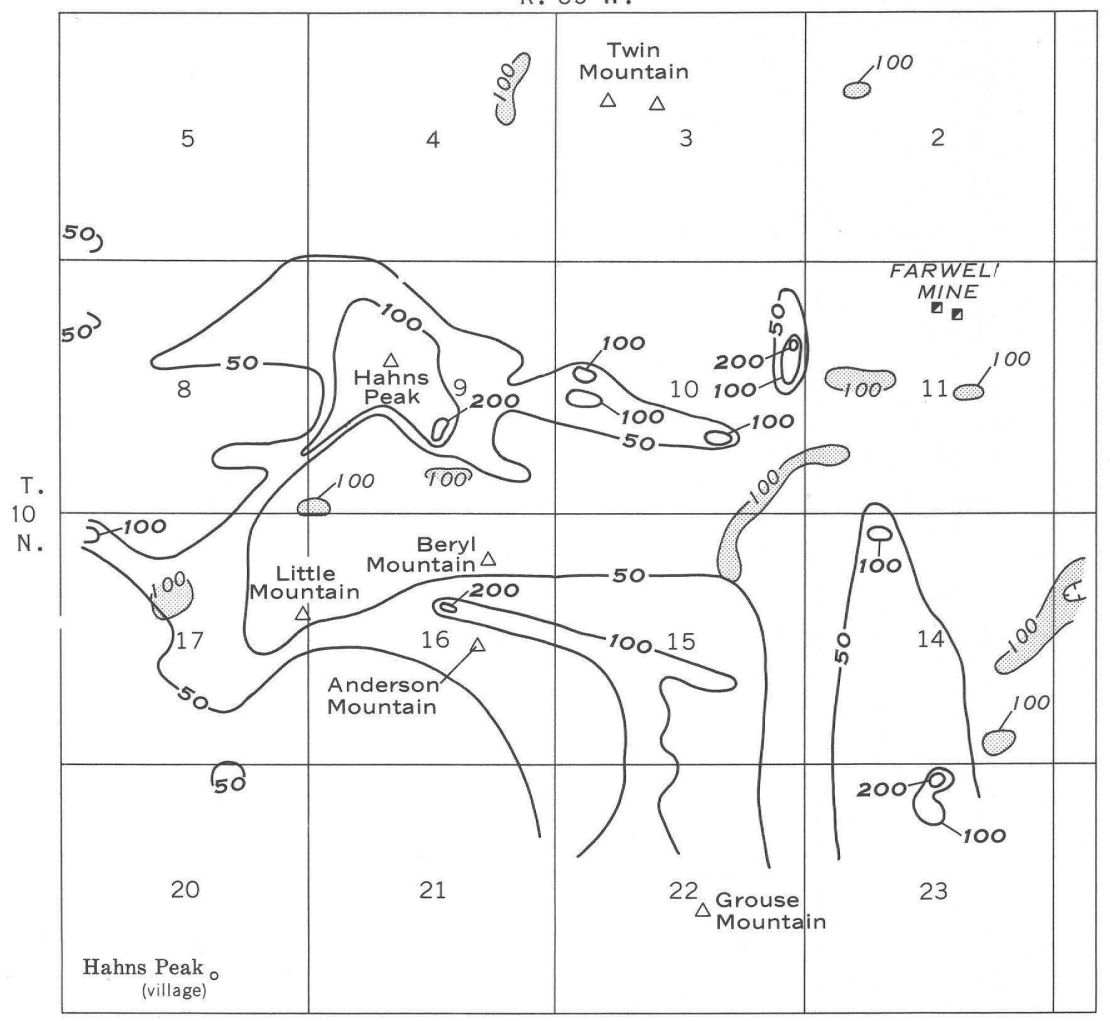

$B$

in the Hahns Peak area. Contours are based on colorimetric analyses of 805 between samples on any line is typically 400 feet. $A$, Ag (patterned) conand $200 \mathrm{ppm}$; and $\mathrm{Zn}$ (patterned) on $100 \mathrm{ppm}$.

fragmented or brecciated than that of the darker variety.

Relatively fresh, gray-brown porphyry dike rock from core (1C in table 1 ) intrudes the main porphyry body. Similar dike rock found at the portal of the $7 \mathrm{D}$ adit is shown in contrast with bleached porphyry in figure 6 .

Although this rock is classified by the Rittmann (1952) system as dark alkali trachyte, the abundance of quartz and the low felsic-mafic index (6.58) indicate that the porphyry is equivalent to quartz andesite. All the rocks listed in table 1, except 1C, are classified as rhyolite porphyries by Rittmann nomenclature, and as rhyolite or alkali rhyolite porphyries (index $>25$ ) by the felsic-mafic index, 


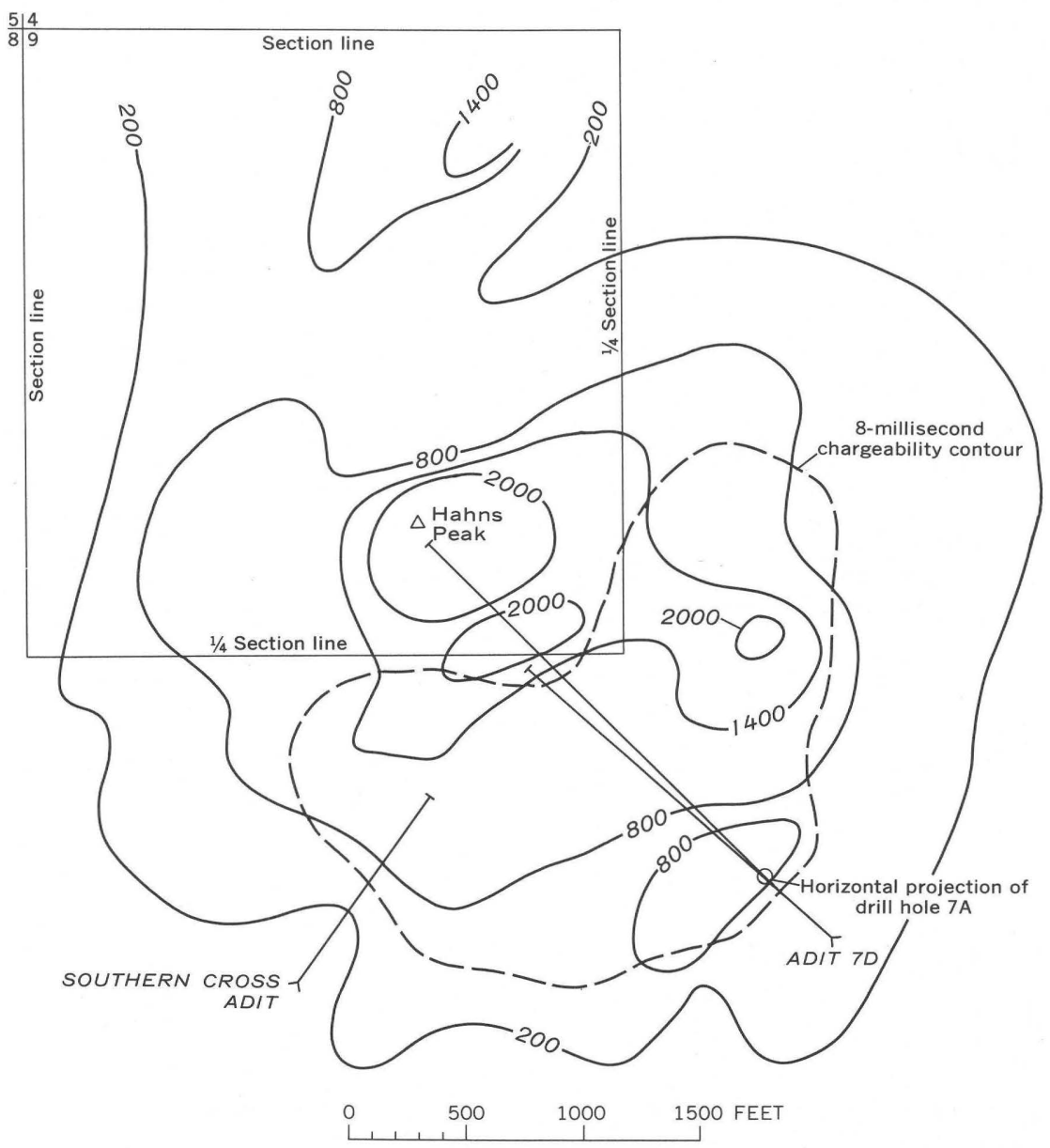

Figure 3.--Induced polarization survey on Hahns Peak. Solid lines are resistivity contours; interval is 600 ohmmeters. Direct-current pulse-transient I.P. survey based on a three-array electrode configuration with 400foot electrode spacing. Data from W. A. Bowes.

$$
\frac{\mathrm{SiO}_{2}+\mathrm{Na}_{2} \mathrm{O}+\mathrm{K}_{2} \mathrm{O}}{\mathrm{FeO}+\mathrm{Fe}_{2} \mathrm{O}_{3}+\mathrm{MgO}+\mathrm{CaO}}
$$

introduced by Segerstrom and Young (1972).

For the purpose of rock classification, modal analyses as given in tables 1 and 2 are misleading where one-half or more of the rock is groundmass. In sample $1 \mathrm{~S}$, for example, quartz was not detected by microscope but was shown-by X-ray analysis to be a major mineral; sanidine and albite are also considerably more abundant than the values shown in the modal analysis; and kao- 


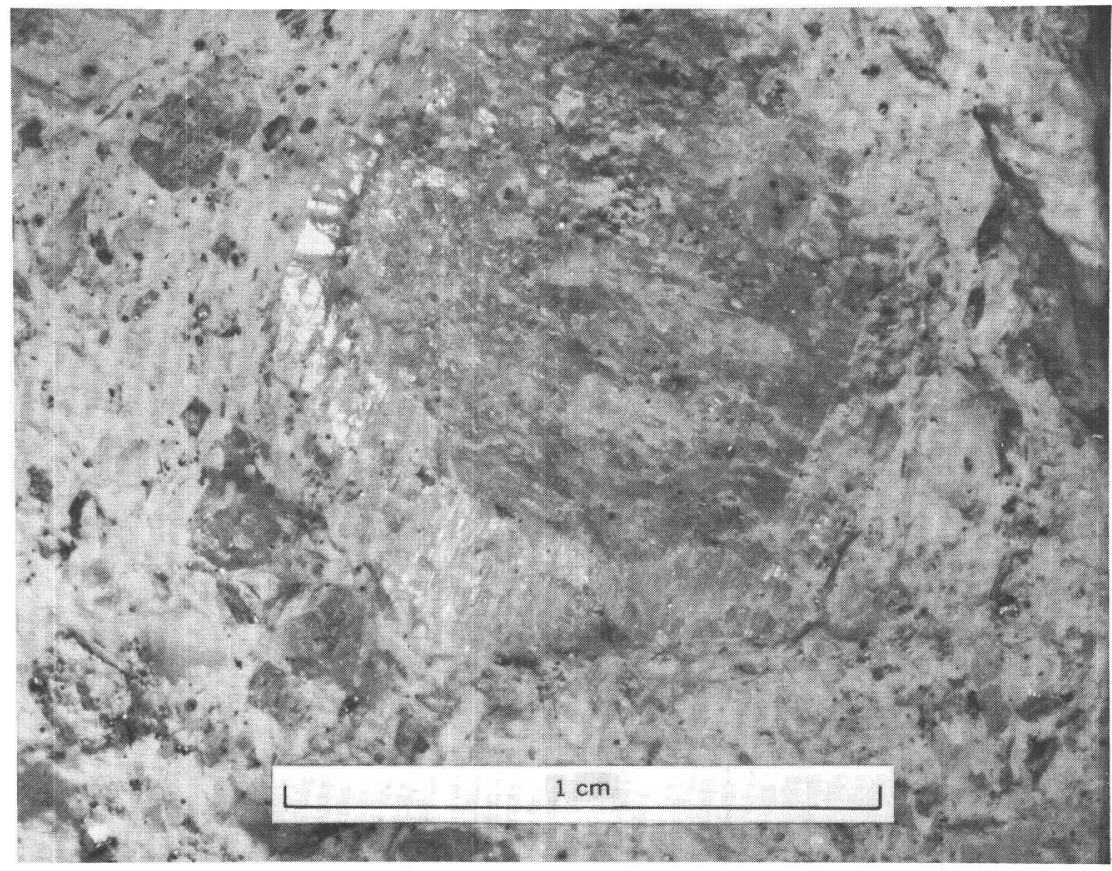

FIGURE 4.-Sanidine phenocryst mantled by secondary albite $(1,667 \mathrm{ft}$ below top of core).

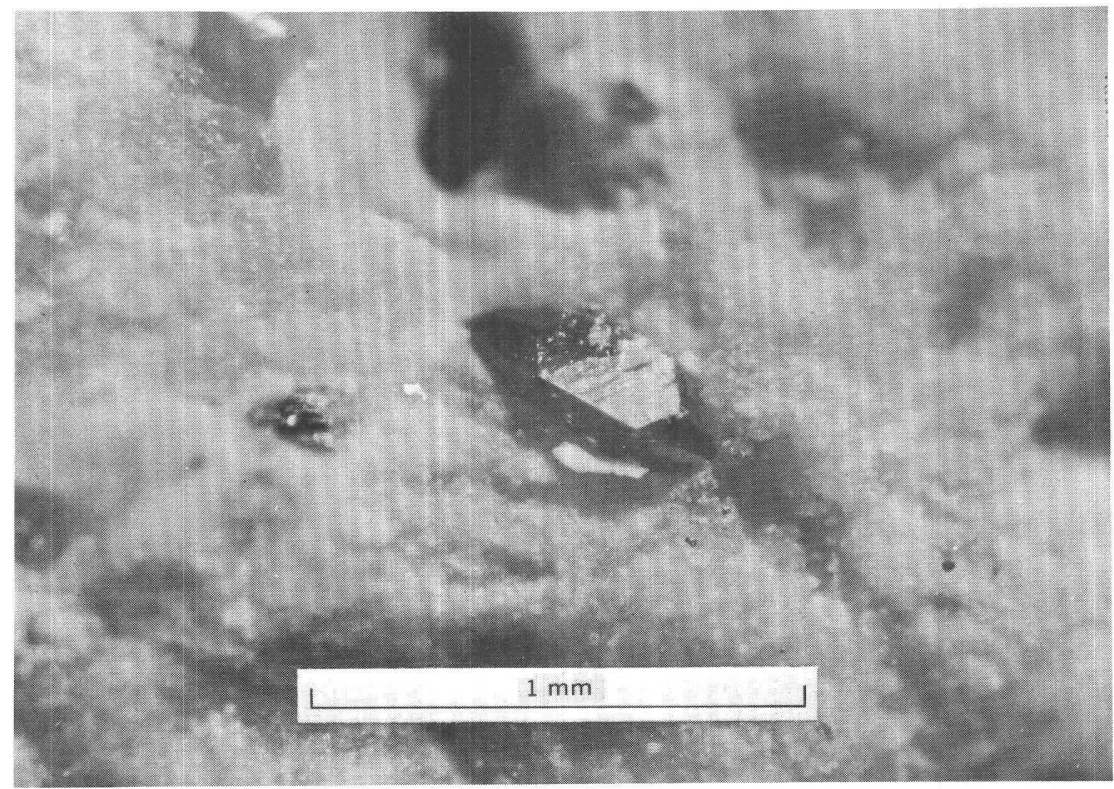

FiguRE 5.-Typical pink zircon crystal occurring as accessory mineral (671 ft below top of core). 
TABLE 1.-Chemical, spectrographic, and modal analyses of porphyry at Hahns Peak [Tr., trace; leaders (--) indicate mineral not observed]

\begin{tabular}{|c|c|c|c|c|c|c|c|c|}
\hline $\begin{array}{l}\text { Sample No. } \\
\text { Laboratory No. (D101-) }\end{array}$ & $\begin{array}{r}1 \mathrm{C} \\
737\end{array}$ & $\begin{array}{r}1 \mathrm{~S} \\
773\end{array}$ & $\begin{array}{r}2 \mathrm{~S} \\
774\end{array}$ & $\begin{array}{r}4 \mathrm{C} \\
775\end{array}$ & $\begin{array}{r}7 \mathrm{C} \\
776\end{array}$ & $\begin{array}{r}33 \mathrm{C} \\
784 \\
\end{array}$ & $\begin{array}{r}38 \mathrm{C} \\
785 \\
\end{array}$ & $\begin{array}{r}41 \mathrm{C} \\
795\end{array}$ \\
\hline \multicolumn{9}{|c|}{ Chemical analyses $^{1}$} \\
\hline $\mathrm{SiO}_{2}$ & 61.64 & 68.19 & 68.16 & 68.00 & 68.00 & 68.63 & 68.26 & 67.50 \\
\hline $\mathrm{Al}_{2} \mathrm{O}_{3}$ & 13.96 & 15.57 & 16.36 & 15.73 & 15.51 & 16.52 & 16.69 & 15.83 \\
\hline $\mathrm{Fe}_{2} \mathrm{O}_{3}$ & 2.15 & 2.43 & $\begin{array}{r}.43 \\
\end{array}$ & 2.17 & 2.71 & .77 & .71 & 2.55 \\
\hline $\mathrm{FeO}$ & 3.06 & .18 & .09 & .07 & .11 & .56 & .72 & .09 \\
\hline $\mathrm{MgO}$ & 2.86 & .32 & .17 & .38 & .42 & .63 & .67 & .32 \\
\hline $\mathrm{CaO}$ & 2.65 & .32 & .21 & .00 & .00 & .28 & .26 & .05 \\
\hline $\mathrm{Na}_{2} \mathrm{O}$ & 4.10 & 2.90 & 1.94 & .17 & .18 & 1.89 & 2.07 & 1.59 \\
\hline $\mathrm{K}_{2} \mathrm{O}$ & 4.88 & 6.24 & 8.63 & 9.27 & 8.10 & 6.34 & 5.96 & 7.79 \\
\hline $\mathrm{H}_{2} \mathrm{O}^{+}$ & .65 & 1.34 & 1.64 & 1.54 & 1.86 & 1.91 & 2.12 & 1.23 \\
\hline $\mathrm{H}_{2} \mathrm{O}^{-}$ & .31 & .37 & .76 & $\begin{array}{r}.69 \\
.69\end{array}$ & .44 & .94 & .87 & .50 \\
\hline $\mathrm{TiO}_{2}$ & .92 & .46 & .37 & .38 & .35 & .56 & .56 & .37 \\
\hline $\mathrm{P}_{2} \mathrm{O}_{5}$ & .63 & .21 & .13 & .02 & .03 & .30 & .27 & .39 \\
\hline $\mathrm{MnO}$ & .14 & .02 & .01 & .01 & $.0 \mathrm{v}$ & .01 & .01 & .01 \\
\hline $\mathrm{BaO}$ & .37 & .18 & .19 & .19 & .16 & .17 & .17 & .20 \\
\hline $\mathrm{CO}_{2}$ & 1.21 & .00 & .00 & .00 & .00 & .01 & .02 & .00 \\
\hline $\mathrm{Cl}$ & .00 & .00 & .01 & .00 & .00 & .01 & .01 & .00 \\
\hline $\mathrm{F}$ & .21 & .11 & .07 & .09 & .10 & .12 & .12 & .11 \\
\hline $\mathrm{S}$ & .05 & .02 & .13 & 1.50 & 2.05 & .05 & .05 & 1.83 \\
\hline Subtotal & 99.79 & 99.86 & 99.30 & 100.21 & 100.35 & 99.70 & 99.54 & 100.36 \\
\hline Less $\mathrm{O}$ for $\mathrm{F}$ and $\mathrm{S}$ & .11 & .06 & .13 & $\begin{array}{r}.79 \\
\end{array}$ & 1.06 & .07 & .07 & .96 \\
\hline Total & 99.68 & 99.80 & 99.17 & 99.42 & 99.29 & 99.63 & 99.47 & 99.40 \\
\hline Felsic-mafic index ${ }^{2}$ & 6.58 & 24.1 & 87.4 & 29.6 & 23.7 & 34.3 & 32.3 & 25.6 \\
\hline
\end{tabular}


Spectrographic analyses ${ }^{3}$

\begin{tabular}{|c|c|c|c|c|c|c|c|c|}
\hline $\mathrm{Ag}$ & $<1$ & $<1$ & $<1$ & $<1$ & 0.5 & $<1$ & $<1$ & $<1$ \\
\hline 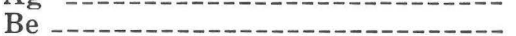 & 3 & 2 & 1.5 & 1.5 & 2 & 2 & 2 & 2 \\
\hline $\mathrm{Ce}$ & 150 & $<150$ & $<150$ & $<150$ & $<150$ & $<150$ & $<150$ & $<150$ \\
\hline Co & 20 & 3 & $<3$ & 3 & 7 & 7 & 5 & $\begin{array}{r}100 \\
7\end{array}$ \\
\hline $\mathrm{Cr}$ & 150 & 50 & 30 & 30 & 30 & 100 & 70 & 30 \\
\hline $\mathrm{Cu}$ & 50 & 1.5 & 10 & 15 & 50 & 15 & 10 & 5 \\
\hline $\mathrm{Ga}$ & 30 & 30 & 50 & 30 & 30 & 30 & 30 & 30 \\
\hline $\mathrm{La}$ & 100 & 50 & 50 & 50 & 50 & 70 & 50 & 30 \\
\hline Mo & 3 & $<3$ & $<3$ & $<3$ & $<3$ & $<3$ & $<3$ & $<3$ \\
\hline $\mathrm{Nb}$ & 10 & $<10$ & $<10$ & $<10$ & $<10$ & $<10$ & $<10$ & $<10$ \\
\hline Nd & 100 & $<70$ & $<70$ & $<70$ & $<70$ & 70 & $<70$ & $<70$ \\
\hline $\mathrm{Ni}$ & 150 & 15 & 7 & 15 & 15 & 30 & 30 & 15 \\
\hline $\mathrm{Pb}$ & 70 & 10 & 150 & 20 & 50 & 50 & 50 & 50 \\
\hline Sc & 10 & 7 & 5 & 5 & 5 & 7 & 7 & 5 \\
\hline $\mathrm{Sr}$ & 1,000 & 200 & 300 & 100 & 150 & 1,000 & 1,000 & 500 \\
\hline $\mathrm{V}$ & 150 & 70 & 50 & 70 & 70 & 70 & 70 & 70 \\
\hline $\mathrm{Y}$ & 15 & 15 & 10 & 10 & 15 & 70 & 70 & 10 \\
\hline $\mathrm{Y} b$ & 1.5 & 1.5 & 1 & 1 & 2 & 5 & 3 & 1.5 \\
\hline $\mathrm{Z} \mathbf{r}$ & 200 & 150 & 150 & 150 & 150 & 200 & 200 & 100 \\
\hline \multicolumn{9}{|c|}{ Modal analyses ${ }^{4}$} \\
\hline Groundmass _-_-_-_- & 79 & 86 & 68 & 63 & 54 & 78 & 74 & 60 \\
\hline Sanidine & .5 & 7 & 12 & 2 & 8 & 5 & 2 & 18 \\
\hline Plagioclase & 5 & 4 & 13 & - & -- & 7 & 14 & 13 \\
\hline Quartz & 2 & -- & 5 & 6 & 13 & 6 & 6 & 7 \\
\hline Biotite & 9 & -- & -- & -- & -- & 4 & 4 & -- \\
\hline Hornblende & 1 & -- & -- & -- & -- & -- & -- & -- \\
\hline Pyroxene & $\overline{3}$ & - & -- & -- & -- & -- & -- & -- \\
\hline Apatite & .5 & Tr. & -- & -- & -- & -- & $\mathrm{Tr}$. & -- \\
\hline Zircon & -- & -- & -- & Tr. & Tr. & Tr. & Tr. & Tr. \\
\hline Sphene & $\mathrm{Tr}$. & -- & -- & -- & -- & -- & -- & -- \\
\hline Magnetite & $\mathrm{Tr}$. & -- & -- & -- & -- & -- & $\operatorname{Tr}$. & -- \\
\hline Sericite & - & 3 & 2 & 27 & 23 & - & - & 1 \\
\hline Pyrite & -- & -- & - & 2 & 2 & Tr. & $\mathrm{Tr}$. & $\mathbf{1}$ \\
\hline Calcite & $\operatorname{Tr}$. & -- & -- & -- & -- & -- & -- & -- \\
\hline
\end{tabular}


Footnotes to table 1 .

${ }^{1}$ Chemical analyses are standard rock analyses by E. E. Engleman (1C), C. L. Parker (1S, 2S, 4C, 7C), V. C. Smith (33C, 38C), G. O. Riddle $(41 \mathrm{C})$, and $\mathrm{E}$. L. Munson, $\mathrm{BaO}$ and $\mathrm{S}$ for all samples except $33 \mathrm{C}$ and $38 \mathrm{C}$, for which $\mathrm{S}$ was estimated from pyrite content and BaO was calculated from spectrographic data.

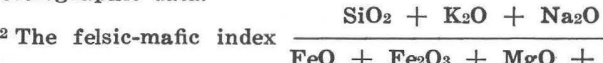

3 Analysts: Harriet $\mathrm{NeimeO}+\mathrm{Fe}_{3} \mathrm{O}_{3}+\mathrm{MgO}+\mathrm{CaO}$

is an indicator of rock composition (Segerstrom and Young, 1972).

(1S, 2S, 4C, 7C, 33C, 38C, 41C). Results are reported in percent to the nearest number in the series 1, 0.7, 0.5, 0.3, 0.2, 0.15, and 0.1, etc.; which represent approximate midpoints of group data on a geometric scale. The assigned group for six-step results will include more accurately determined values about so percent of the time. The lollowing ele theses were looked for and not found: $\mathrm{As}(2,000), \operatorname{Au}(20), \mathbf{B}(20), \mathbf{B i}(10), \mathrm{Cd}(50), \operatorname{Eu}(100), \operatorname{Ge}(10), \operatorname{Hf}(100), \operatorname{In}(10), \operatorname{Li}(100), \operatorname{Pd}(2), \operatorname{Pr}(100), \operatorname{Pt}(50)$, Re(50), Sb(200), Sm(100), Sn(10), Ta (200), Te(2,000), Th(200), Tl(50), U(500), W (100), Zn (200).

Modal analyses are based on approximately 400 points per thin section. Sericite, calcite, and pyrite are secondary minerals. Plagioclase in $1 \mathrm{C}$ is oligoclase, in all other samples plagioclase is albite. No.

$1 \mathrm{C}$----1S

Description of samples

$4 \mathrm{C}, \overline{7} \mathrm{C}, 33 \mathrm{C}, 38 \mathrm{C}, 41 \mathrm{C}-$ Altered rhyolite porphyry from core $7 \mathrm{~A}$ at depths (feet) of $59,253.5,1,158.5$, 1,254, and 1,361 . 33C and $38 \mathrm{C}$ are from dikes. 


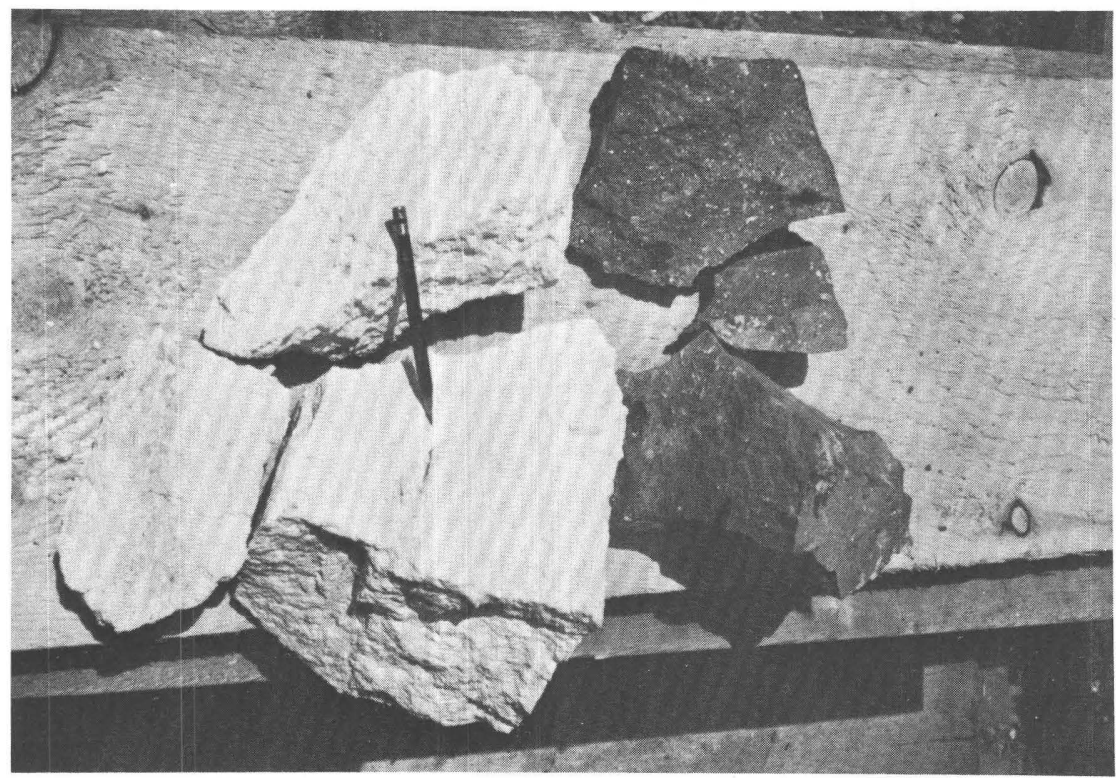

Figure 6.-Bleached porphyry of Hahns Peak (similar to sample 2S in table 1), on left, and dark quartz andesite porphyry dike rock from the portal of the $7 \mathrm{D}$ adit (similar to sample $1 \mathrm{C}$ in table 1), on right.

linite, which could not be identified with the microscope, was shown by X-ray to be a minor constituent. Kaolinite, generally in trace amounts, was detected by X-ray in all the samples listed in table 1 except 1C. Montmorillonite and jarosite, in none of the samples as abundant as sericite and kaolinite, were detected by $\mathrm{X}$-ray in the upper part of core $7 \mathrm{~A}$ as shown on plate 2 .

Chemical changes encountered in core $7 \mathrm{~A}$ (taible 1) are reflected by mineral changes shown on plate 2 . The major change is the complete replacement of albite by sericite and kaolinite in the upper part of the core. The rock of this zone is also the host for most of the ore minerals. The lowermost part of the core also shows replacement of albite by sericite and kaolinite, but mineralization there was not as pervasive as in the upper part.

Especially to be noted in table 1 is the virtual absence of $\mathrm{CaO}$ in samples $4 \mathrm{C}, 7 \mathrm{C}$, and $41 \mathrm{C}$. Inasmuch as samples $4 \mathrm{C}$ and $7 \mathrm{C}$ correspond to the zone of replaced albite their values of $\mathrm{Na}_{2} \mathrm{O}$ also are very low. Sample $41 \mathrm{C}$ at 1,361 feet is below the zone of replaced albite, hence the $\mathrm{Na}_{2} \mathrm{O}$ value is almost 10 times higher in it than in $4 \mathrm{C}$ and $7 \mathrm{C}$. Enrichment of the most altered rock with $\mathrm{K}_{2} \mathrm{O}$ is evident also. Barium is generally high in all the rocks 
TABLE 2.-Modal analyses of porphyry at Hahns Peak in core $7 A$, in percent [Modal analyses are based on about 400 points per thin section.
Tr., trace; leaders (

\begin{tabular}{|c|c|c|c|c|c|c|c|c|c|c|c|c|c|c|}
\hline $\begin{array}{l}\text { Sample No. } \\
\text { Depth in core (ft) }\end{array}$ & $\begin{array}{l}12 \mathrm{C} \\
292.5\end{array}$ & $\begin{array}{l}16 \mathrm{C} \\
356.5\end{array}$ & $\begin{array}{l}17 \mathrm{C} \\
4.06\end{array}$ & $\begin{array}{c}42 \mathrm{C} \\
1,394\end{array}$ & $\begin{array}{c}43 \mathrm{C} \\
1,400\end{array}$ & $\begin{array}{r}44 \mathrm{C} \\
1,421\end{array}$ & $\begin{array}{c}45 \mathrm{C} \\
1,428.5\end{array}$ & $\begin{array}{c}46 \mathrm{C} \\
1,495.5\end{array}$ & $\begin{array}{c}47 \mathrm{C} \\
1,557\end{array}$ & $\begin{array}{r}48 \mathrm{C} \\
1,989\end{array}$ & $\begin{array}{c}49 \mathrm{C} \\
2,146\end{array}$ & $\begin{array}{c}50 \mathrm{C} \\
2,204\end{array}$ & $\begin{array}{c}53 \mathrm{C} \\
2,908\end{array}$ & $\begin{array}{c}54 \mathrm{C} \\
3,150\end{array}$ \\
\hline Groundmass _-_. & 65 & 58 & 55 & 56 & 50 & 57 & 51 & 78 & 69 & 77 & 70 & 60 & 72 & 68 \\
\hline 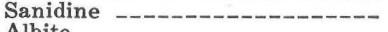 & 6 & 4 & 9 & 15 & 13 & 10 & 14 & 7 & 8.5 & 7 & 2.5 & 24 & 2 & 5 \\
\hline Albite & & & & 16 & 19 & 24 & 14 & 7 & 11.5 & 6 & $1 \overline{5}$ & 2 & $1 \overline{8}$ & \\
\hline Quartz & 16 & 31 & 18 & 7 & 6 & 3 & 12 & 5 & 4 & 1.5 & 4 & 1 & Tr. & 24 \\
\hline Apatite ------ & & & -- & & Tr. & Tr. & .5 & Tr. & Tr. & $\mathbf{T 5}$ & Tr. & Tr. & .5 & .5 \\
\hline $\begin{array}{l}\text { Zircon } \\
\text { Pyrite }{ }^{1}-1-\end{array}$ & Tr. & Tr. & $-\overline{3}$ & Tr. & $-\overline{2}$ & $-\overline{3}$ & $\overline{1}$ & $\overline{1}$ & Tr. & Tr. & --5 & $-\overline{1}$ & -- & $\overline{1}$ \\
\hline $\begin{array}{l}\text { Pyrite }{ }^{1} \text { Sericite }^{1}-1- \\
\end{array}$ & $\begin{array}{r}1 \\
12\end{array}$ & $\begin{array}{l}1 \\
6\end{array}$ & 15 & $\begin{array}{l}1 \\
5\end{array}$ & $\begin{array}{l}2 \\
4\end{array}$ & $\begin{array}{l}3 \\
3\end{array}$ & $\begin{array}{l}1 \\
2\end{array}$ & $\begin{array}{l}1 \\
2\end{array}$ & $\frac{1.5}{5}$ & $\begin{array}{l}2 \\
6\end{array}$ & $6^{.5}$ & $\begin{array}{l}1 \\
4\end{array}$ & $\overline{3}$ & $\begin{array}{l}1 \\
2\end{array}$ \\
\hline Manganosiderite 1 & -- & -- & -- & -- & 6 & -- & 6 & -- & -- & -- & 2 & -- & -- & -- \\
\hline Calcite $^{1}$, & -- & -- & -- & -- & -- & -- & -- & -- & -- & -- & -- & 8 & 4 & -- \\
\hline Chlorite $^{1}$ & -- & -- & -- & -- & -- & -- & -- & -- & -- & -- & -- & -- & .5 & -- \\
\hline
\end{tabular}

${ }^{1}$ Secondary mineral. 
of table 1, which suggests enrichment of the sanidine. High sulfur values in samples $4 \mathrm{C}, 7 \mathrm{C}$, and $41 \mathrm{C}$ are attributable to pyrite content. Samples 33C and $38 \mathrm{C}$ are of dike porphyries which have been altered to rhyolite porphyry. Their higher contents of $\mathrm{MgO}$, $\mathrm{CaO}, \mathrm{Na}_{2} \mathrm{O}$, and $\mathrm{TiO}_{2}$ than those of surrounding rock, in addition to the preservation of unaltered biotite, signify their differences from most of the porphyry. Nevertheless, they are intensely altered compared to the fresh dike rock of 1C. Among the trace elements, $\mathrm{Sr}$ and $\mathrm{Cr}$ are more abundant in these three dike rocks than in surrounding rock.

The porphyry at Hahns Peak in the upper third of core 7A, as shown in table 3, is almost depleted of $\mathrm{CaO}$ and, to a lesser extent, of $\mathrm{Na}_{2} \mathrm{O}$. The ore elements, $\mathrm{Ag}, \mathrm{Pb}, \mathrm{Zn}$, and $\mathrm{Cu}$, show fluctuations depending on the presence or absence of disseminated ore minerals. Mn enrichment generally corresponds with $\mathrm{Fe}$ enrichment and is caused by secondary manganosiderite in the lower part of the core as shown on plate 2 .

Albite is absent in the uppermost and lowermost parts of the core as shown in table 2. Zircons are sparse but may be found anywhere; being resistant they show no evidence of chemical attack. Apatite is a very common accessory mineral below about 1,400 feet in the core; it is extremely sparse or absent above 1,400 feet.

The most extensive and pervasive hydrothermal alteration processes were those of sericitization, kaolinization, and silicification. The process of pyritization was also common, but it represents addition rather than alteration. Alterations by jarosite, limonite, and montmorillonite were minor by comparison and were generally confined to near-surface levels; these kinds of alterations indicate weathering. Secondary sanidine and an ironmanganese carbonate are present locally, and secondary anatase is a minor, but widespread, alteration product. Calcite, barite, and carbonate fluorapatite are sparse secondary minerals. Variscite and wavellite developed in the ore mineral zones.

The most extensive alteration of the rock in core $7 \mathrm{~A}$ was that caused by sericitization ( $\mathrm{pl}$. 2). Albite and biotite were the most susceptible of all minerals to replacement by sericite. In the upper part of the core, former albite phenocrysts were completely replaced by soft white aggregates of sericite, kaolinite, montmorillonite, and opal in complex mixtures. Jarosite and manganosiderite admixtures may color these aggregates yellow to brown. Sericite has completely replaced biotite throughout the core except in the dike rocks $(1 \mathrm{C}, 33 \mathrm{C}$, and $38 \mathrm{C}$ in table 1$)$. The former black biotite hexagonal phenocrysts have been trans- 
TABLE 3.-Spectrographic analysis of

[Spectrographic analyses by G. W. Sears, Jr. Results are reported in percent to the nearest midpoints of group data on a geometric scale. The assigned group for six-step results elements with detectability limits in parentheses were looked for but not found: As $(2,000)$, (100), Pt(50), Re(50), Sb(200), Sm(100) Sn(10), Ta(200), Te(2,000), Th(200), Ti

\begin{tabular}{|c|c|c|c|c|c|c|c|c|c|}
\hline \multirow{3}{*}{$\begin{array}{l}\text { Sample No. -- } \\
\text { Laboratory } \\
\text { No. (D128-) } \\
\text { Depth in core } \\
\text { (ft) }\end{array}$} & $11 \mathrm{C}$ & $15 \mathrm{C}$ & $26 \mathrm{C}$ & $27 \mathrm{C}$ & $29 \mathrm{C}$ & $30 \mathrm{C}$ & $31 \mathrm{C}$ & $32 \mathrm{C}$ & $37 \mathrm{C}$ \\
\hline & 096 & 097 & 352 & 353 & 354 & 355 & 356 & 942 & 357 \\
\hline & 292 & 340 & 839.5 & 910 & 999 & 1,020 & 1,059 & 1,095 & 1,250 \\
\hline \multicolumn{10}{|r|}{ Weigh } \\
\hline $\mathrm{Si}$ & $>10$ & $>10$ & $>10$ & $>10$ & $>10$ & $>10$ & $>10$ & $>10$ & $>10$ \\
\hline $\mathrm{Al} \ldots \ldots$ & 7 & 10 & 7 & 7 & 7 & 5 & 7 & 7 & 10 \\
\hline $\mathrm{Fe}$ & 2 & 5 & 2 & 2 & 1.5 & 1.5 & 7 & 1.5 & 5 \\
\hline $\mathrm{Mg}$ & .3 & .3 & .15 & .15 & .07 & .1 & .15 & .07 & .15 \\
\hline $\mathrm{Ca}$ & .02 & .01 & .02 & .015 & .015 & .02 & .015 & .01 & .05 \\
\hline $\mathrm{Na}$ & .3 & .3 & 1.5 & .2 & 1 & .7 & 1 & 2 & .7 \\
\hline $\mathrm{K},-\cdots-----$ & 7 & 7 & 7 & 5 & 7 & 3 & 7 & 7 & 10 \\
\hline Ti --------- & 1.5 & .2 & .2 & .15 & .2 & .1 & .15 & .2 & .3 \\
\hline
\end{tabular}

\begin{tabular}{|c|c|c|c|c|c|c|c|c|c|c|}
\hline & & & & & & & & & & arts per \\
\hline $\mathrm{Ag}$ & --------- & 0.5 & 5 & 70 & 7 & 30 & 3 & 100 & $<1$ & 1 \\
\hline $\mathrm{Ba}$ & -- & 2,000 & 2,000 & 2,000 & 1,500 & 2,000 & 1.000 & 2,000 & 3,000 & 2,000 \\
\hline $\mathrm{Be}$ & $--0-0-1$ & 1.5 & 1.5 & 1.5 & $\begin{array}{r}1,000 \\
1.5\end{array}$ & 1.5 & $\begin{array}{r}1.000 \\
1.5\end{array}$ & 1.5 & 1 & 1.5 \\
\hline Co & - & 7 & 7 & 7 & 7 & 7 & 5 & 15 & 7 & 20 \\
\hline $\mathrm{Cr}$ & - & 30 & 30 & 30 & 20 & 20 & 15 & 15 & 30 & 70 \\
\hline $\mathrm{Cu}$ & $---0---$ & 7 & 100 & 300 & 200 & 300 & 10 & 700 & 70 & 30 \\
\hline $\mathrm{Ga}$ & - & 30 & 30 & 30 & 20 & 20 & 10 & 30 & 30 & 30 \\
\hline $\mathrm{La}$ & --- - - - - - & 30 & 30 & 70 & 30 & 30 & 30 & 30 & 30 & 70 \\
\hline $\mathrm{Mn}$ & - & 20 & 50 & 10 & 20 & 20 & 15 & 70 & 20 & 50 \\
\hline & ------ & 5 & 7 & $<3$ & $<3$ & $<3$ & $<3$ & 10 & $<3$ & 10 \\
\hline $\mathrm{Nb}$ & $\ldots$ & $<10$ & $<10$ & $<10$ & $<10$ & $<10$ & $<10$ & $<10$ & $<10$ & 10 \\
\hline & - - - & $<70$ & $<70$ & $<70$ & $<70$ & $<70$ & $<70$ & $<70$ & $<70$ & 70 \\
\hline $\mathrm{Ni}$ & -- - - - - & 20 & 15 & 15 & 20 & 15 & 10 & 30 & 15 & 150 \\
\hline $\mathrm{Pb}$ & - & 1,000 & 500 & 50 & 500 & 70 & 30 & 10,000 & 50 & 70 \\
\hline $\mathrm{Sc}$ & - & 5 & 5 & 5 & 5 & 5 & $<5$ & 5 & 5 & 7 \\
\hline $\mathrm{Sr}$ & - & 100 & 150 & 300 & 150 & 200 & 100 & 300 & 300 & 500 \\
\hline $\mathrm{V}$ & 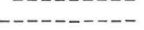 & 70 & 100 & 70 & 30 & 50 & 20 & 50 & 70 & 70 \\
\hline & - & 15 & 15 & 10 & $<10$ & $<10$ & $<10$ & 10 & 10 & 20 \\
\hline $\mathrm{Y} b$ & - & 1.5 & 1.5 & 2 & 1 & 1 & $<1$ & 1.5 & 1.5 & 2 \\
\hline$\overline{\mathbf{Z}}_{\mathrm{n}}$ & - - - - - & $<200$ & 1,000 & $<200$ & 1,500 & $<200$ & 200 & 5,000 & $<200$ & $<200$ \\
\hline $\mathrm{Z}_{\mathrm{r}}$ & - & 100 & 150 & 150 & $\begin{array}{l}150 \\
150\end{array}$ & 150 & 70 & 100 & 150 & 200 \\
\hline
\end{tabular}

formed to gray-white sericite aggregates. The core is reddish orange if manganosiderite is also present.

Kaolinization was not quite as extensive as sericitization (pl. 2) but it was widespread. The purest kaolinite is found as soft white replacements of albite, but most kaolinite occurs as mixtures with sericite, montmorillonite, and opal.

Silicification was very common and usually resulted in hard, dark-gray irregular zones or veinlets in the softer, whiter porphyry. These siliceous zones represent incomplete replacement of porphyry and, as shown by X-ray analysis, they are similar to unsilicified groundmass except that they contain more quartz. Another much less common form of silicification was the formation of small quartz crystals which line small cavities. The largest crystals are $4 \times 1 \frac{1}{2} \mathrm{~mm}$, but most crystals are smaller than $1 \mathrm{~mm}$. Even sparser are crusts of chalcedony.

Pyrite occurs throughout the core except for the upper 40 feet where pyrite has been altered to jarosite. Pyrite abundance is generally 1-2 percent by volume. Pyrite shows several textural 
porphyry at Hahns Peak in core $7 \mathrm{~A}$

number in the series $1,0.7,0.5,0.3,0.2,0.15$, and 0.1 , tc., which represents approximate will include more accurately determined values about 30 percent of the time. The following $\mathrm{Au}(20), \mathrm{B}(20), \mathrm{Bi}(10), \mathrm{Cd}(50), \mathrm{Eu}(100), \mathrm{Ge}(10), \mathrm{Hf}(100), \operatorname{In}(10), \mathrm{Li}(100), \mathrm{Pd}(2), \mathrm{Pr}$ (50), Ú(500), W(100), Zn (200)]

\begin{tabular}{|c|c|c|c|c|c|c|c|c|}
\hline $42 \mathrm{C}$ & $43 \mathrm{C}$ & $44 \mathrm{C}$ & $45 \mathrm{C}$ & $46 \mathrm{C}$ & $47 \mathrm{C}$ & $55 \mathrm{C}$ & $56 \mathrm{C}$ & $57 \mathrm{C}$ \\
\hline 433 & 434 & 435 & 436 & 437 & 438 & 943 & 944 & 945 \\
\hline 1,394 & 1,400 & 1,421 & $1,428.5$ & $1,495.5$ & 1,557 & 2,204 & 2,773 & 3,150 \\
\hline \multicolumn{9}{|l|}{ percent } \\
\hline $\begin{array}{r}>10 \\
10 \\
1 \\
\\
3^{.15} \\
.2\end{array}$ & $\begin{array}{l}>10 \\
>10 \\
7 \\
.3 \\
.3 \\
3^{.3} \\
.15\end{array}$ & $\begin{array}{c}>10 \\
>10 \\
.7 \\
.15 \\
3_{5}^{.15} \\
.2\end{array}$ & $\begin{array}{r}>10 \\
>10 \\
7.3 \\
.3 \\
3^{.3} \\
{ }^{3} \\
.2\end{array}$ & $\begin{array}{c}>10 \\
7 \\
1 \\
.07 \\
.15 \\
1.5 \\
3 \\
.1\end{array}$ & $\begin{array}{c}>10 \\
>10 \\
2 \\
.3 \\
.3 \\
3^{.3} \\
.15\end{array}$ & $\begin{array}{l}10 \\
7 \\
3 \\
1^{1} \\
2 \\
7 \\
.15\end{array}$ & $\begin{array}{c}>10 \\
7 \\
3 \\
.7 \\
.15 \\
7^{.3} \\
.2\end{array}$ & $\begin{array}{c}>10 \\
7 \\
1.5 \\
.3 \\
.15 \\
7^{.3} \\
.3\end{array}$ \\
\hline
\end{tabular}

million

\begin{tabular}{|c|c|c|c|c|c|c|c|c|}
\hline$<1$ & $<1$ & $<1$ & $<1$ & 50 & $<1$ & $<1$ & 3 & $<1$ \\
\hline 2,000 & 1,500 & 2,000 & 2,000 & 1,500 & 2,000 & 3,000 & 3,000 & 2,000 \\
\hline 3 & 3 & 3 & 3 & 2 & 3 & 1.5 & 3 & 2 \\
\hline 7 & 10 & 7 & 15 & 7 & 7 & 7 & 10 & 7 \\
\hline 30 & 20 & 30 & 30 & 15 & 30 & 30 & 30 & 70 \\
\hline 1 & $<1$ & $<1$ & $<1$ & 30 & $<1$ & & & \\
\hline 30 & 30 & 30 & 30 & 15 & 30 & 30 & 30 & 30 \\
\hline 50 & 50 & 50 & 50 & 50 & 50 & 30 & 30 & 30 \\
\hline 20 & 3,000 & 30 & 3,000 & 30 & 70 & 1,500 & 150 & 50 \\
\hline$<3$ & $<3$ & $<3$ & $<3$ & 70 & $<3$ & $<3$ & $<3$ & $<3$ \\
\hline$<70$ & $<70$ & $\begin{array}{l}<10 \\
<70\end{array}$ & $\begin{array}{l}<10 \\
<70\end{array}$ & $\begin{array}{l}<10 \\
<70\end{array}$ & $<70$ & $<70$ & $\begin{array}{l}<10 \\
<70\end{array}$ & $\begin{array}{l}<10 \\
<70\end{array}$ \\
\hline 15 & 30 & 15 & 30 & 10 & 15 & 15 & 30 & 20 \\
\hline 20 & 15 & 30 & 70 & 15,000 & 20 & 20 & 1,000 & 70 \\
\hline 5 & 5 & 5 & 5 & $<5$ & 5 & 5 & 7 & 7 \\
\hline 700 & 500 & 700 & 700 & 200 & 700 & 500 & 700 & 300 \\
\hline 70 & 50 & 70 & 50 & 50 & 15 & 50 & 100 & 100 \\
\hline 10 & 15 & 15 & 15 & $<10$ & 15 & 10 & 15 & 20 \\
\hline 1.5 & 2 & 1.5 & 1.5 & 1 & 1.5 & 1 & 1 & 3 \\
\hline$<200$ & $<200$ & $<200$ & 200 & 200 & $<200^{\circ}$ & $<200$ & 200 & $<200$ \\
\hline 100 & 70 & 100 & 150 & 70 & 150 & 150 & 150 & 300 \\
\hline
\end{tabular}

forms, the most common and widespread being small (usually $<1 \mathrm{~mm}$ ) disseminated pyritohedrons. Locally grain size is finer than the pyritohedrons, and small clots and aggregates of the crystals occur. Less common is the occurrence of veinlets of pyrite, which may be several millimeters wide but generally are thinner. Just below the major mineralized zone, at about 1,200 feet in the core, platelets of aggregated pyrite crystals occur in small cavities. Some platelets are hexagonal in form and are pseudomorphs of biotite. An unusual starlike platelet is shown in figure 7 . Fracture surfaces in the altered porphyry are locally coated with thin black crusts of pyrite. Below 2,800 feet in the core, pyrite occurs as large cubes as much as $1 \mathrm{~cm}$ in diameter. Pyrite is late in the paragenetic sequence, as are the ore minerals. It encrusts quartz crystals and chalcedony in cavities and occurs as inclusions in secondary sanidine.

Jarosite crusts and limonite stains are sporadic but common in the uppermost parts of the core. They are attributable to the weathering of pyrite, inasmuch as pyrite is absent or occurs 


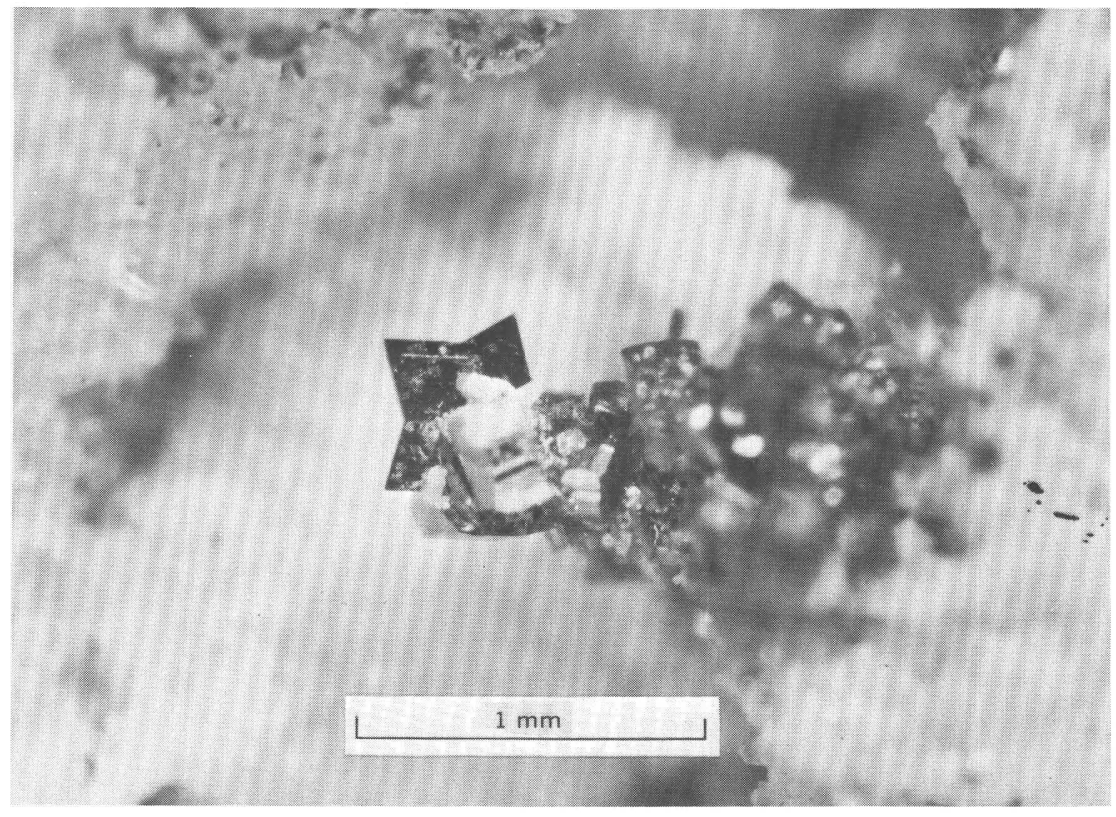

Figure 7.-Starlike platelet of pyrite $(1,202 \mathrm{ft}$ below top of core).

only in trace amounts in this zone. Montmorillonite (pl. 2) occurs in trace amounts, generally in the upper parts of the core. It is generally the admixed constituent of altered albite phenocrysts.

Colorless crystals of secondary sanidine have been found in small cavities. The (201) X-ray method (Tuttle and Bowen, 1958 ) indicates that they contain 95 percent orthoclase molecule.

Manganosiderite (pl. 2) occurs sporadically in the lower part of the core, below the major mineralized zone. Characteristically it colors the porphyry and, particularly, the albite yellow and brown. Alteration of the albite locally yielded brown soft phenocrysts, which consist of the manganosiderite and a sericitemontmorillonite mixed-layer mineral. Some of the manganosiderite probably resulted from the breakdown of pyrite, as the following observation shows. Thin veinlets of pyrite were noted surrounded by yellow-brown alteration products. One such veinlet cut an albite phenocryst, which was dark brown instead of the pale yellow of albite phenocrysts away from the veinlet. Pyrite of the veinlet was tarnished black.

Anatase, a minor but very pervasive alteration product, occurs predominantly as crystals and to a lesser degree as disseminated grains. The crystals, which are only $0.01-0.05 \mathrm{~mm}$ in size, are clove brown or black; and they occur as the lining of small (average size about $2 \times 1 / 2 \mathrm{~mm}$ ) microvugs (fig. $8 A$ ). These microvugs 


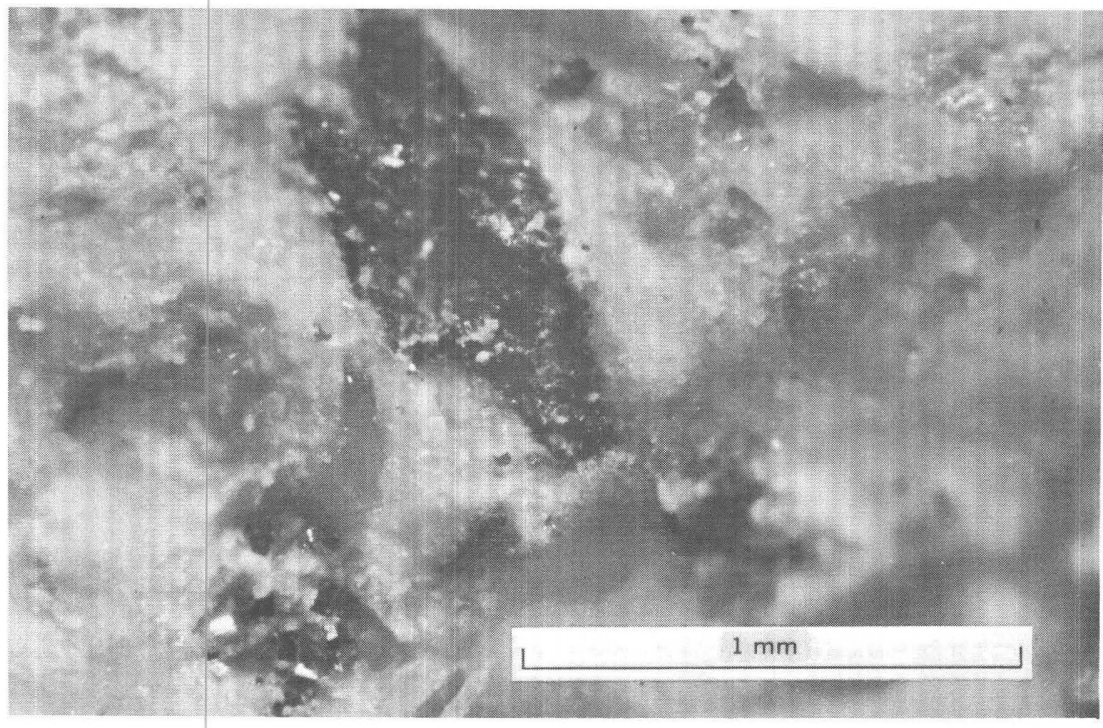

$A$

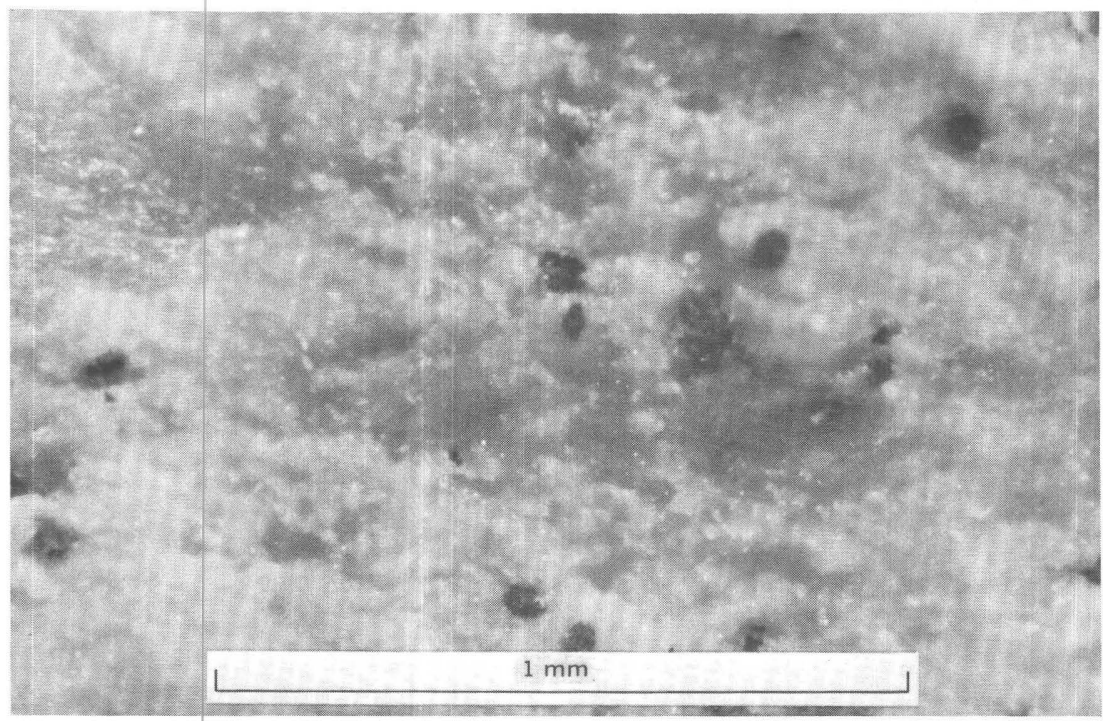

$B$

Figure 8.-Two modes of occurrence of secondary anatase. $A$, In microvugs. $B$, Disseminated grains. (Anatase from $990.5 \mathrm{ft}$ below top of core.)

are common, but total volume of the anatase in the rock is $<1$ percent. The shape of the microvugs suggests that they were formerly sphene crystals. Mitchell (1964) described anatase pseu- 
domorphs after sphene in pegmatite from Virginia. The disseminated grains of anatase (fig. $8 B$ ) are of about the same size as the crystals.

Calcite is very sparse, having been seen in only one place, where it occurred in an open fracture with ore minerals. Barite is also sparse; it was observed as clear yellow plates in association with sphalerite in cores 3 and 7B. Carbonate fluorapatite was noted as a cream-colored encrustation on pyrite at one place in core 7A, where it resulted from the alteration of fluorapatite.

Variscite and wavellite are important secondary minerals. They are described with their associated ore minerals in the next section.

The breccia zones shown on plate 2 contain black shale, either as fragments or as smeared-out remnants of fragments. At about 2,600 feet in core 7A fragments of Precambrian granite gneiss were noted in several places. Granite gneiss is easily identified in thin section because of its abundant microcline content. The penetrating pyritization of the porphyry had also affected these gneiss fragments, as shown by the fact that they contain many disseminated pyrite crystals.

\section{DISSEMINATED ORE MINERAL OCCURRENCE}

\section{ORE MINERALOGY}

Galena and sphalerite are the two most abundant ore minerals in the porphyry at Hahns Peak. Silver-bearing tetrahedrite occurs locally; chalcopyrite and, especially, proustite and covellite are sparse. Most of the galena occurs as disseminations or as clots whose diameter averages a few millimeters and only rarely reaches $1 \mathrm{~cm}$. Some galena occurs as veinlets that are $2 \mathrm{~mm}$ thick or less. Plate 2 shows the distribution of galena and the other ore minerals in core 7A. Rather common in the galena zone from 580-920 feet are pyrite crystals and grains which contain galena as central cores. Sphalerite occurs in the same manner as galena, but overall it is less abundant than galena. An impression gained from study of many cores is that sphalerite forms larger clots than galena. The sphalerite ranges in color from black through brown to pale yellow.

Silver-bearing tetrahedrite occurs as small $(1 \mathrm{~mm})$ tetrahedrons in small cavities, as shown in figure 9. Several lines of evidence indicate that this mineral has a composition between tetrahedrite- $(\mathrm{CuZnFe})_{12} \mathrm{Sb}_{4} \mathrm{~S}_{13}$ - and freibergite (argentian tetrahedrite $)-(\mathrm{CuAgZnFe})_{12} \mathrm{Sb}_{4} \mathrm{~S}_{13}$. Data from Berry and Thompson (1962) show a diagnostic X-ray peak at $d=1.855$ A for frei- 


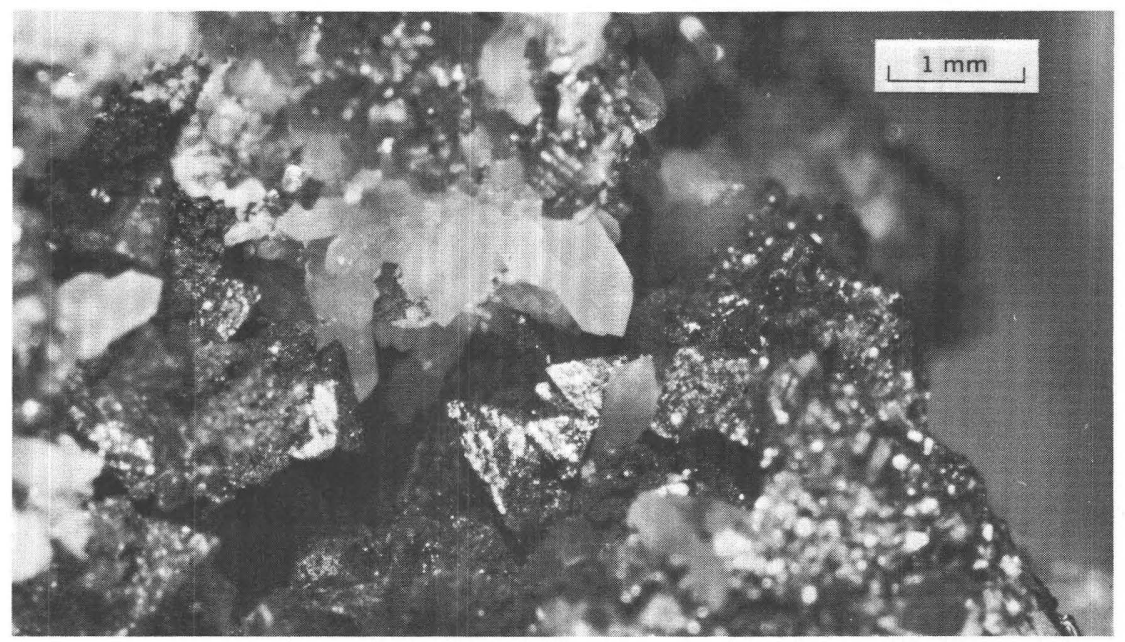

Figure 9.-Silver-bearing tetrahedrite (tetrahedrons) and quartz crystals in small cavity (271.5 ft below top of core).

bergite and $\mathrm{d}=1.831 \mathrm{~A}$ for tetrahedrite. The corresponding peak for the tetrahedrite from Hahns Peak is $d=1.841 \mathrm{~A}$. In addition Berry and Thompson (1962) listed unit cell parameters of tetrahedrite and freibergite as $\mathrm{a}=10.37 \mathrm{~A}$ and $\mathrm{a}=10.48 \mathrm{~A}$, respectively. Unit cell size of the Hahns Peak tetrahedrite is $10.41 \mathrm{~A}$. Hence we conclude that the Hahns Peak tetrahedrite lies between end member tetrahedrite and end member freibergite.

Proustite is a very sparse mineral, occurring in small quantities as grains or small crystals (fig. 10) in association with silverbearing tetrahedrite.

Chalcopyrite is also sparse and usually occurs as small tetrahedrons with or near silver-bearing tetrahedrite. In polished section, blebs of chalcopyrite have been seen in the tetrahedrite.

Covellite is very sparse, and it occurs in cavities with other ore minerals or as inclusions or cores in pyrite.

Variscite, $\mathrm{AlPO}_{4} \cdot 2 \mathrm{H}_{2} \mathrm{O}$, occurs intimately and abundantly with the ore minerals. Wavellite, $\mathrm{Al}(\mathrm{OH})_{3}\left(\mathrm{PO}_{4}\right) \cdot 5 \mathrm{H}_{2} 0$, occurs just below the major ore mineral zone. These two minerals bear an inverse relation to the primary fluorapatite which is common below the zone of aluminum phosphates but which is virtually absent in and above that zone. Fluorapatite is very soluble in acid solutions, and the solvent action would liberate $\mathrm{PO}_{4}^{-3}$. Alumina, resulting from the alteration of feldspar, could combine with the phosphate anion to form wavellite and variscite. Variscite assumes several different forms, but the most common is 


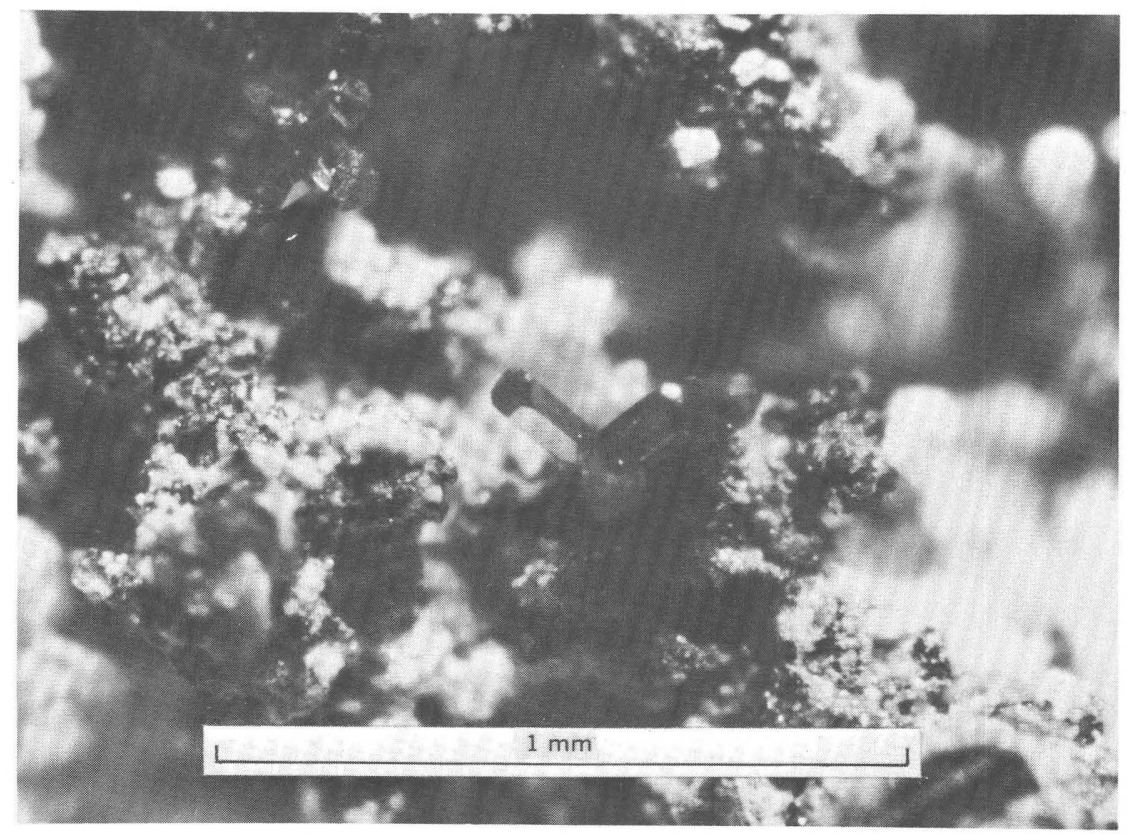

Figure 10.-Proustite prisms. Dark mineral, sphalerite; light mineral, variscite ( $836 \mathrm{ft}$ below top of core).

as pale- to sea-green botryoidal crusts which line cavities (fig. 11). Cross sections through the crusts reveal a radially fibrous structure. Less common are colorless crusts. Another common form consists of colorless or white, soft spherules, mostly less than $1 \mathrm{~mm}$ across, in cavities. More than one generation of variscite was shown by glassy variscite encrusting milky white variscite.

Wavellite is sparser than variscite (pl. 2). It occurs chiefly as colorless botryoidal crusts (fig. 12) and less commonly as colorless spherules. Where wavellite and variscite were found together, wavellite encrusted variscite.

Aluminum phosphates, although not common as gangue minerals in hydrothermal deposits, occur in several places. In the tin ores of Llallagua, Bolivia, wavellite is abundant and variscite is less so, both being secondary following the breakdown of apatite (Gordon, 1944). Variscite, in addition to other secondary phosphates, has been found in the oxidation zone of hydrothermal siderite in Slovakia (Koch and Sarudi, 1963).

Eight samples of porphyry, about evenly spaced through the core of drill hole 7A and averaging about 5 grams in weight, 


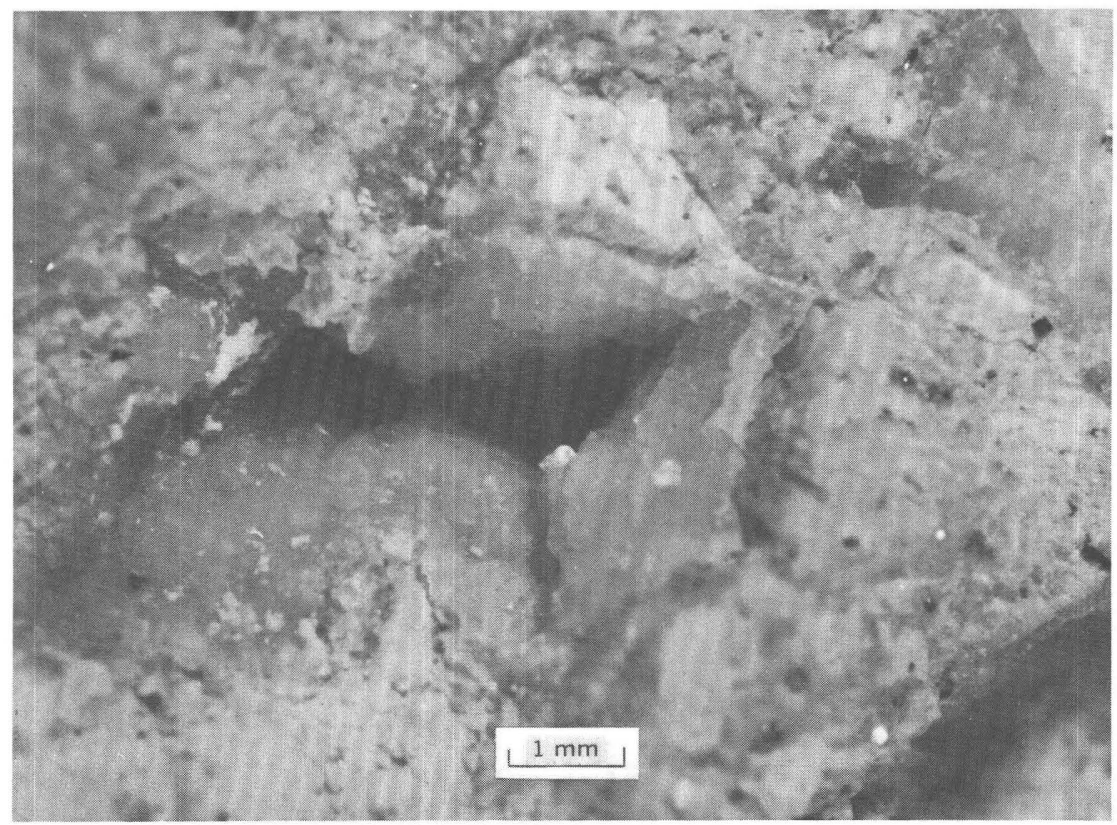

FIgURE 11.-Pale-green botryoidal crusts of variscite lining a cavity (426 ft below top of core).

were placed in hydrofluoric acid, and insoluble residues, chiefly pyrite, were obtained. The spectrographic analyses of these residues are given in table 4 . The fact that the residues are not entirely pyrite accounts for most of the trace elements found. Elements such as silicon, titanium, and zirconium can be explained by the presence of zircon and anatase. More interesting, however, are the amounts of base metals and silver in the residues. The largest amount of silver is in sample 3, which contains relatively small amounts of copper, lead, and zinc. This ratio suggests that silver may be derived from a mineral such as proustite or that it may be in solid solution in the pyrite. Sporadically high amounts of lead, zinc, and copper most probably are due to admixtures of galena, sphalerite, and chalcopyrite. The analyses indicate that copper may increase with depth, leaving open the question of how it actually occurs. The problem of how base metals are lodged in pyrite, whether as mineral inclusions or as solid solution, has found opposing advocates in two recent papers. Sutherland (1967), in a study of New Brunswick pyrites, found that most, if not all, of the lead, zinc, copper, and arsenic could be traced to mineral inclusions; whereas Einaudi (1968) reported 


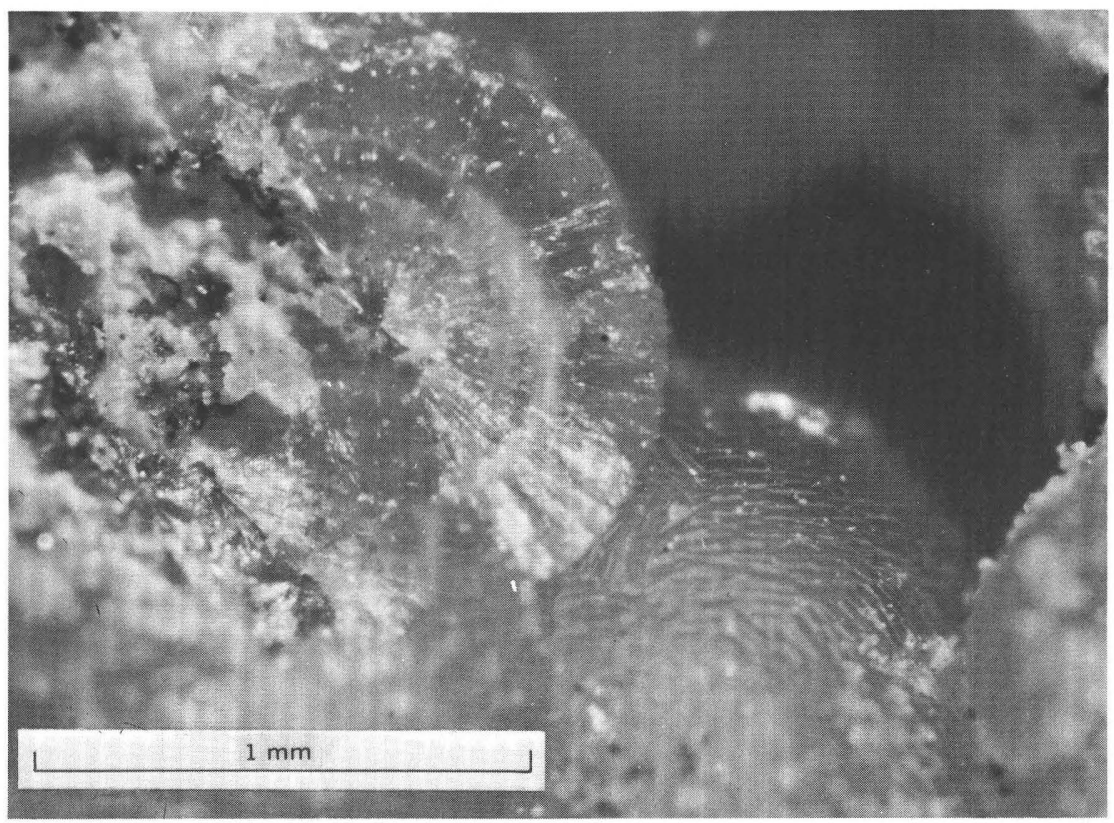

FIGURE 12.-Botryoids of wavellite in a cavity (1,166 ft below top of core).

that as much as 1.5 percent copper was held in solid solution in pyrite.

\section{PARAGENETIC SEQUENCE}

The one fact of paragenetic sequence that seems clear is that the various types of rock alteration, such as sericitization, kaolinization, silicification, and formation of secondary anatase, preceded the emplacement of ore minerals. All ore minerals and pyrite were deposited more or less simultaneously, as shown by intergrowths and mutually overlapping relationships. Variscite and wavellite tend to follow ore mineral emplacement as shown by the fact that they commonly encrust ore minerals and pyrite. This sequence is complicated, however, by pyrite inclusions found in some of these aluminum phosphates, and by pyrite both encrusting and being encrusted by the phosphate minerals.

\section{EXTENT AND PROBABLE GRADE OF THE ANOMALY}

The average values for silver, lead, zinc, copper, and molybdenum for each of the Hahns Peak drill holes and adits for which analytical data exist are given in table 5, together with the crustal abundances of these elements as reported by Vinogradov 
TABLE 4.-Spectrographic analyses, in parts per million, of pyrite concentrates from porphyry at Hahns Peak recovered in core $7 \mathrm{~A}$

[Spectrographic analyses by R. H. Heidel. Results are to be identified with geometric brackets whose boundaries are $1.2,0.83,0.56,0.38,0.26,0.18,0.12$, etc., but are reported arbitrarily as midpoints of these brackets, $1.0,0.7,0.5,0.3,0.2,0.15,0.1$, etc. The precision of a reported value is approximately plus or minus one bracket at 68 -percent, or two brackets at 95-percent confidence. Looked for but not found (detection limits in parentheses): $\mathrm{P}(5,000), \mathrm{Au}(20), \mathrm{B}(20), \mathrm{Be}(1), \mathrm{Bi}(10), \mathrm{Cd}(50), \operatorname{Mo}(3), \mathrm{Pd}(2), \mathrm{Pt}(50), \mathrm{Sb}(200)$, Sn(10), Te(2,000), U (500), W(100), Ce(150), Ga(5), Ge(10), Hf(100), In (10), Li(100), Re(50), Ta(200), Th(200); Tl(50), $\operatorname{Pr}(100), \operatorname{Nd}(70), \operatorname{Sm}(100), \operatorname{Eu}(100)]$

\begin{tabular}{|c|c|c|c|c|c|c|c|c|}
\hline $\begin{array}{l}\text { ample No. } \\
\text { Pepth of core }(\mathrm{ft}) \\
\text { percentage of } \\
\text { pyrite in sample }\end{array}$ & $\begin{array}{c}1 \\
457 \\
3.32\end{array}$ & $\begin{array}{c}2 \\
792 \\
1.33\end{array}$ & $\begin{array}{c}3 \\
1,211\end{array}$ & $\begin{array}{l}4 \\
.611\end{array}$ & $\begin{array}{c}5 \\
2,002 \\
2.69\end{array}$ & $\begin{array}{c}6 \\
2,410 \\
1.70\end{array}$ & $\begin{array}{l}7 \\
2,821 \\
4.17\end{array}$ & $\begin{array}{c}8 \\
3,168\end{array}$ \\
\hline 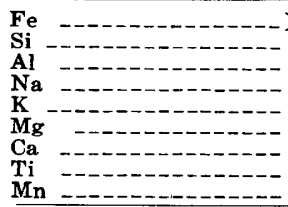 & $\begin{array}{r}00,000 \\
7,000 \\
3,000 \\
<500 \\
7,000 \\
1,500 \\
500 \\
3,000 \\
30\end{array}$ & $\begin{array}{r}00,000 \\
5,000 \\
1,000 \\
<500 \\
7,000 \\
300 \\
500 \\
3,000 \\
30\end{array}$ & $\begin{array}{r}5,000 \\
2,000 \\
<500 \\
7,000 \\
300 \\
500 \\
>10,000 \\
30\end{array}$ & $\begin{array}{r}10,000 \\
3,000 \\
<500 \\
<7,000 \\
150 \\
300 \\
3.000 \\
70\end{array}$ & $\begin{array}{r}3,0 \\
<50 \\
7,0 \\
1 \\
2 \\
\mathbf{5 , 0}\end{array}$ & $\begin{array}{r}2,0 \\
<5 \\
7,0 \\
5 \\
7 \\
1,5\end{array}$ & 3, & $\begin{array}{r}10,000 \\
300 \\
<500 \\
7,000 \\
100 \\
100 \\
1,500 \\
10 \\
\end{array}$ \\
\hline 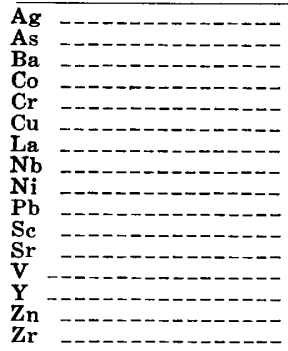 & $\begin{array}{r}100 \\
150 \\
200 \\
150 \\
100 \\
30 \\
300 \\
300 \\
<5 \\
15 \\
7 \\
20 \\
2,000 \\
700\end{array}$ & $\begin{array}{r}20 \\
150 \\
30 \\
200 \\
<30 \\
10 \\
700 \\
3,000 \\
<5 \\
7 \\
10 \\
10 \\
7,000 \\
1,500\end{array}$ & $\begin{array}{r}200 \\
15 \\
7 \\
50 \\
<10 \\
500 \\
700\end{array}$ & $\begin{array}{r}30 \\
300 \\
150 \\
<5 \\
5 \\
10 \\
<10 \\
10,000 \\
1,500\end{array}$ & $\begin{array}{r}5 \\
10 \\
15 \\
<10 \\
1,500 \\
1,000\end{array}$ & $\begin{array}{r}7 \\
7 \\
<10 \\
3,000 \\
1,500\end{array}$ & $\begin{array}{r}<5 \\
70 \\
7 \\
<10 \\
<200 \\
150\end{array}$ & $\begin{array}{r}10,000 \\
<30 \\
10 \\
500 \\
300 \\
<5 \\
<5 \\
<7 \\
<10 \\
3,000 \\
300\end{array}$ \\
\hline
\end{tabular}

Description of $\mathrm{HF}$ residues

Sample No.

1 -_.___- Pyritohedrons (1 $\mathrm{mm}$ and less), $<1$ percent pale pink zircon.

2 Similar to 1 , pyritohedrons smaller.

3 - Similar to 1 with addition of some pyrite clusters in very fine grained platy aggregates and some unidentified milky-white soft material.

4 -..... More contaminants than 1, some black grains (sphalerite), more zircon than 1 , many platy pyrite aggregates.

5 ------ Similar to 1.

6 - Pyrite in cubes from slightly $<10<0.1 \mathrm{~mm}$, some platy aggregates, more zircon than 1 .

7 - - - - Pyrithohedrons and cubes, 2 cubes $4 \mathrm{~mm}$, less zircon than 1 .

8 - Pyrite mostly as cubes as large as $0.5 \mathrm{~mm}$, but most $0.1 \mathrm{~mm}$ or less, less zircon than 1 .

(1962). The distribution of the Hahns Peak values shows that the area immediately southeast of the peak is the most anomalous, as already indicated by geophysical and geochemical surveys. Comparison with the crustal abundances clearly indicates that of the five elements, silver and lead are the most highly anomalous, molybdenum and zinc are somewhat less anomalous, and copper is only slightly anomalous. Gold content probably is anomalously high, but this could not be confirmed because of insufficient analytical data owing to the small amounts of gold found. The gold content of 98 selected samples (those with higher gold values) averages $0.2 \mathrm{ppm}$; it ranges from 0.02 to $3.2 \mathrm{ppm}$ as determined by atomic absorption methods. Only three of the 98 samples contained more than $1 \mathrm{ppm}$ gold. 
TABle 5.-Average values for $A g, P b, Z n, C u$, and $M o$ in Hahns Peak drill holes and adits, and comparison with crustal abundances

[Locations of drill holes and adits are shown on pl. 1. Most analyses are spectrographic; some are atomic absorption and fire assay ]

\begin{tabular}{|c|c|c|c|c|c|c|}
\hline \multirow{3}{*}{$\begin{array}{c}\text { Drill } \\
\text { hole } \\
\text { or } \\
\text { adit }\end{array}$} & \multirow{3}{*}{$\begin{array}{c}\text { Number } \\
\text { of } \\
\text { samples } \\
\text { averaged }\end{array}$} & \multicolumn{5}{|c|}{ Average value } \\
\hline & & \multicolumn{3}{|c|}{ Weight percent } & \multirow{2}{*}{$\begin{array}{c}\text { Parts } \\
\text { Ag }\end{array}$} & \multirow{2}{*}{$\begin{array}{r}\text { per million } \\
\text { Mo }\end{array}$} \\
\hline & & $\mathbf{C u}$ & $\mathrm{Pb}$ & $\mathbf{Z n}$ & & \\
\hline ------_--- & 65 & 0.006 & 0.016 & 0.032 & 6 & 6 \\
\hline$-\ldots$ & 10 & .003 & .017 & .013 & 27 & 3 \\
\hline $2 \mathrm{~A}$ & 32 & .007 & .163 & .021 & 15 & 9 \\
\hline 3 & 37 & .023 & .328 & .066 & 18 & 51 \\
\hline 4 & 24 & .002 & .021 & .015 & 5 & 1 \\
\hline 5 & 4 & .014 & .052 & .014 & 8 & 8 \\
\hline 6 & 13 & .003 & .017 & .008 & 1 & 2 \\
\hline 7 & 31 & .01 & .033 & .016 & $1 \overline{9}$ & 10 \\
\hline -.- & 211 & .007 & .084 & .047 & 9 & 5 \\
\hline$---1-1-$ & 127 & .007 & .021 & .014 & 7 & 7 \\
\hline $7 \mathrm{D}$ (adit) & 225 & .013 & .144 & .131 & 6 & 9 \\
\hline $7 \mathrm{D} 2$ & 138 & .003 & .02 & .017 & 3 & 3 \\
\hline 8 & 8 & .019 & .009 & .011 & 3 & 7 \\
\hline 9 & 7 & .004 & .012 & .010 & 3 & 10 \\
\hline 17 & 30 & .011 & .14 & .1 & 17 & 11 \\
\hline 19 & 6 & .004 & .009 & .008 & .5 & 4 \\
\hline 30 & 57 & .003 & .019 & .023 & 2.5 & 1 \\
\hline 31 & 70 & .003 & .016 & .023 & 1.4 & $\overline{\mathbf{5}}$ \\
\hline $34 \mathrm{~A}$ & 5 & .009 & .007 & .008 & 24 & 3 \\
\hline $36 \mathrm{~B}$ & 29 & .002 & .004 & .01 & .3 & 2 \\
\hline 37 - & 16 & .003 & .004 & .008 & 1 & 6 \\
\hline D1 _ & 17 & .005 & .058 & .014 & 24 & $\mathbf{5}$ \\
\hline D2 & 23 & .089 & 2.51 & .537 & 42 & 152 \\
\hline D4 & 83 & .022 & .084 & .125 & 18 & 17 \\
\hline $\begin{array}{l}\text { Southern Cross } \\
\text { (adit) }\end{array}$ & 38 & 003 & $0 ?$ & 01 & $?$ & 5 \\
\hline & 00 & . UVo & .02 & & & \\
\hline Total _...-.- & 1,306 & 0.01 & 0.11 & 0.06 & 9.7 & 10.4 \\
\hline $\begin{array}{l}\text { Crustal abundance } \\
\text { (Vinogradov, 1962) }\end{array}$ & $-\ldots$ & 0.005 & 0.002 & 0.008 & 0.07 & 1 \\
\hline average & value & & & & & \\
\hline crustal abu & andance & 2 & 55 & 7.5 & 140 & 10 \\
\hline
\end{tabular}

Adit 7D and drill holes 7A, D2, and 37 are almost in the same northwest-trending vertical plane ( $\mathrm{pl} .1$ ). On this plane silver values are plotted on plate $3 A$ and lead values on plate $3 B$. From these two figures it is seen that the zone with the most promising silver-lead potential is in the vicinity of the intersection of drill hole D2 with adit 7D. To focus more attention on this zone, the analytical data for silver, lead, and zinc in the vicinity of this intersection are shown on plate $3 C$. Except for very few sporadic highs, copper and molybdenum values are negligible. Drill hole D4 also penetrates near this intersection, and silver and lead values in this core are shown on plate $3 D$. Higher values in the vicinity of the intersection are evident. Drill hole 3 also penetrates 109 feet below this intersection, and silver and lead values in this core are shown on plate $3 E$. 
The amount of metals in the vicinity of the intersection of drill hole 2 and adit 7D was estimated using a volume of rock $400 \times 400 \times 100$ feet. These dimensions include the most intensely mineralized rock along $7 \mathrm{D}$ and $\mathrm{D} 2$, and a conservative projection to 50 feet on either side of the plane $7 \mathrm{D}$ and D2. Assuming a specific gravity of 2.6 , this volume of rock contains $1.3 \times 10^{6}$ short tons; ore grade, estimated from the data shown on plate 3 , averages $20 \mathrm{ppm} \mathrm{Ag}$ ( $0.58 \mathrm{oz}$ per short ton), 0.5 percent $\mathrm{Pb}$, and 0.2 percent $\mathrm{Zn}$. Amounts of metals present are 26 tons Ag, 6,500 tons $\mathrm{Pb}$, and 2,600 tons $\mathrm{Zn}$. Total value of the metals-using average 1970 prices of $\$ 1.60$ per oz for $\mathrm{Ag}, \$ 0.16$ per pound $\mathrm{Pb}$, and $\$ 0.15$ per pound $\mathrm{Zn}-$ is about $\$ 4$ million, or $\$ 3.12$ per ton.

This oversimplified calculation is intended to suggest only that additional exploratory drilling in the area of the 7D-D2 intersection may be warranted either to enlarge the tonnage of known mineralized rock and to improve the grade data or to reveal higher grade, perhaps economic, concentrations of metals. Nevertheless, the hydrothermally altered porphyry at Hahns Peak, far from being economically valuable at the present time, is anomalous enough possibly to warrant future consideration as a low-grade resource. From table 5 let us take the average values for $\mathrm{Ag}$ as $10 \mathrm{ppm}$ ( $0.29 \mathrm{oz}$ per short ton), $\mathrm{Pb}$ as 0.1 percent, and $\mathrm{Zn}$ as 0.06 percent. If we make the approximate area of the drill coverage 3,500 times 2,500 feet, and the depth 1,000 feet, we have a volume of $8.7 \times 10^{9}$ cubic feet. Using a density of 2.6 for the porphyry, this volume weighs $7.1 \times 10^{8}$ tons and contains 7,100 tons of $\mathrm{Ag}, 710,000$ tons of $\mathrm{Pb}$, and 430,000 tons of $\mathrm{Zn}$. In this large volume, the total value of metals, based on the previously mentioned prices, is about $\$ 690$ million or about $\$ 0.97$ per ton.

\section{REFERENCES CITED}

Antweiler, J. C., Doe, B. R., and Delevaux, M. H., 1972, Lead isotope and other evidence on the bedrock source of placer gold at Hahns Peak, Colorado: Econ. Geology, v. 67, no. 3, p. 302-314.

Antweiler, J. C., and Sutton, A. L., Jr., 1970, Spectrochemical analyses of native gold samples: U.S. Geol. Survey rept., 28 p.; available only from the Natl. Tech. Inf. Service, U.S. Dept. Commerce, Springfield, Va. 22151, NTIS PB1-94809.

Barnwell, W. W., 1955, The geology of the south Hahns Peak district, Routt County, Colorado, in Intermountain Assoc. Petroleum Geologists Guidebook 6th Ann. Field Conf., northwest Colorado, 1955: Salt Lake City, Utah, p. 73-75.

Berry, L. G., and Thompson, R. M., 1962, X-ray powder data for ore minerals-The Peacock atlas: Geol. Soc. America Mem. 85, 281 p. 
Buffler, R. T., 1967, The Browns Park Formation and its relationship to the late Tertiary geologic history of the Elkhead region, northwestern Colorado-south-central Wyoming: California Univ., unpub. Ph.D. thesis; Ann Arbor, Mich., Univ. Microfilms, Inc., 215 p.

Christensen, A. L., 1942, Igneous geology of the Elkhead Mountains, Colorado: California Univ., unpub. Ph.D. thesis, 180 p.

del Rio, S. M., compiler, 1960, Mineral resources of Colorado, first sequel: Denver, Colo., Colorado Mineral Resources Board, 764 p.

Einaudi, M. T., 1968, Copper zoning in pyrite from Cerro de Pasco, Peru: Am. Mineralogist, v. 53, p. 1748-1752.

Emmons, S. F., 1877, Elkhead Mountains, in Hague, Arnold, and Emmons, S. F., Descriptive geology: U.S. Geol. Exploration of the 40th Parallel, v. 2 , p. $167-180$.

Gale, H. S., 1906, The Hahns Peak gold field, Colorado: U. S. Geol. Survey Bull. 285-H, p. 28-34.

George, R. D., and Crawford, R. D., 1909, The Hahns Peak region, Routt County, Colorado: Colorado Geol. Survey 1st Rept., p. 189-229.

Gordon, S. G., 1944, The mineralogy of the tin mines of Cerro de Llallagua, Bolivia: Acad. Nat. Sci. Philadelphia Proc., v. 96, p. 279-359.

Gosling, A. W., Jenne, E. A., and Chao, T. T., 1971, Gold content of natural waters in Colorado: Econ. Geology, v. 66, no. 2, p. 309-313.

Hall, Frank, 1895, History of the state of Colorado, 1889-1895: Chicago, Rocky Mountain Historical Co., 4 v.

Hunter, J. M., 1955, Geology of the North Hahns Peak area, Routt County, Colorado, in Intermountain Assoc. Petroleum Geologists Guidebook 6th Ann. Field Conf., northwest Colorado, 1955: p. 71-72.

King, Clarence, 1878, Systematic geology: U.S. Geol. Exploration of the 40th Parallel, v. 1, 803 p.

Koch, S., and Sarudi, I., 1963, The hydrous basic aluminum phosphates of Zeleznik (Vashegy), Slovakia (CSSR) : Acta Mineralog.-Petrog., Univ. Szedediensis, Szeded, Hungaria, v. 16, no. 1, p. 3-10.

McConnell, M. D., 1960, The geology of the Clark-Hinman Park area, Routt County, Colorado: Wyoming Univ., unpub. M.S. thesis, $67 \mathrm{p}$.

Mitchell, R. S., 1964, Pseudomorphs of anatase after sphene from Roanoke County, Virginia: Am. Mineralogist, v. 49, nos. 7-8, p. 1136-1139.

Murphy, R. H., 1958, Geology of the Slavonia-Diamond Park area, Routt County, Colorado: Wyoming Univ., unpub. M.S. thesis, 54 p.

Parker, B. H., Jr., 1961, The geology of the gold placers of Colorado: Colorado School Mines, unpub. Ph.D. dissert., 543 p.

Rittmann, Alfred, 1952, Nomenclature of volcanic rocks proposed for the use in the catalogue of volcanoes, and key-tables for the determination of volcanic rocks: Bull. Volcanol., ser. 2, v. 12, p. 75-102; discussion, p. 24-26.

Segerstrom, Kenneth, and Kirby, S. H., 1969, Tuffaceous epiclastic breccia and sandstone near Hahns Peak, Colorado, and their genetic implications, in Geological Survey research 1969: U.S. Geol. Survey Prof. Paper 650-B, p. B19-B22.

Segerstrom, Kenneth, and Young, E. J., 1972, General geology of the Hahns Peak and Farwell Mountain quadrangles, Routt County, Colorado, with a discussion of Triassic and Jurassic rocks, by G. N. Pipiringos: U.S. Geol. Survey Bull. 1349 (in press). 
Sutherland, J. K., 1967, The chemistry of some New Brunswick pyrites: Canadian Mineralogist, v. 9, pt. 1, p. 71-84.

Tuttle, O. F., and Bowen, N. M., 1958, Origin of granite in the light of experimental studies in the system $\mathrm{NaAlSi}_{3} \mathrm{O}_{8} \mathrm{KAlSi}_{3} \mathrm{O}_{5}-\mathrm{SiO}_{2}-\mathrm{H}_{2} \mathrm{O}$ : Geol. Soc. America Mem. 74, 153 p.

Vinogradov, A. P., 1962, Average contents of chemical elements in the principal types of igneous rocks of the earth's crust: Geokhimiya 1962, no. 7, p. 555-571 (in Russian) ; translation in Geochemistry, 1962, no. 7, p. 641-664. 

